UC-11

Reporting Date: March 1976 Issued: July 1976

\title{
Long-Term Ecoiogical Effects of Exposure to Uranium
}

by

Wayne C. Hanson

Felix R. Miera, Jr. 
This is a Completion Report of Project Order 5.5066-244 to Reimbursable Activities Branch, US Energy Research and Development Administration, Albuquerque, NM, from the US Air Force Armament Laboratory, Eglin AFB, FL.

Printed in the United States of America. Available from Nationai Technical Information Service

U.S. Department of Commerce

5285 Port Royal Rond

Springfield, VA 22161

Price: Printed Copy \$4.00 Microfiche \$2.2S 
Abstract

I. Introduction

II. The LASL Area

II. LASL Uranium Study sites

IV. Methods

A. Sample Collection

B. Sampie Analyses

C. Comparison of Eberline and LASL Chexicel Anelyaes of Soil urentur.

v. Results and Discussion

A. Uraniun concentrations in EnFB soll samples

B. Uranium Concentrations in LASL soll Samples

C. Uranium Concentrations in WSL Biota

VI. Biotic Survey of LASI Study sites

A. Plant Comunity Anajysis the stung sites

B. Small Mamal Populations Aseocieted with the plant Comanites

C. Small Macrcfauna of Soll and Litter at Last study sites

1. Populations and Characterietles

2. Abundance of varlous specios and Groups in Test and control areas

VII. Summary and Conelueions

References

Appendix A. IASL Urasium Study Sites

Appendix B. Results of tranium analyaes of soil Samples

Appendix C. Quality Control Data for LAsL Uranium hnalyas

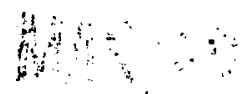


LORG-TERY ECOLOGICAL EFEECTS OF EXPOSURE TO URANIUM

by

Wayne C. Unson and Felix R. Mierar. Jr.

\section{ABSTRACT}

The conseguences of roleasing notural and depleted uranium to terzestrial ecosystems during development and testing of depleted uranium aunltions were inveseigated. At Eglin Air Force Base. Florida, soil at various distances from armor plate target buts struck by depluted uraniun penetrators was sampied. The upper $5 \mathrm{~cm}$ of soil ht the target bases contained an average of Boo ppa of depleted uranium, atout 30 times as much as soil at 5- to 10-cm depth, Indicating some vertical movement of depleted urasilum. Samples collected beyoni about $20 \mathrm{~m}$ from the targets showed near-background natural uranium level:s, about 1.3:0.3:9/9 or jogr.

Two explosives-testing areas at the Los Alamos Scientifle Laboratory (LASL) were selected because of their use history. E-F Site soil averaged 2400 pps of uranium in the upper $5 \mathrm{~cm}$ and $1600 \mathrm{ppw}$ at $5-10 \mathrm{~cm}$. Lower lilobovia sile soil from two subplots ayersged about 2.5 and 0.61 of the $E-F$ site concentrations. important uraniun concentration iffferences with depth and dis. tance from detonstion points were asteribed to the different explosive tosts conducted in cach area.

E-F site vegetation sampleg contained about $320 \mathrm{ppm}$ of uranium in November 1974 and about 125 ppm in Juns 1975. Smal1 mamals trapped in the seudy armas in November contained a max:mum of 210 pom of uranitu in tha gastrointestinal tract contents, 24 ppm in the pelt, and 4 ppm in the remaining carcass. In June, maximum concentrations were 110,50 , and 2 Fpm in similar samples and $6 \mathrm{ppon}$ in lungs. These data emphasized the importance of resuspension of respirable particles in the upper few millimeters of soil as a contamination mechanism for several components of the UASL ecosystem.

\section{IMTRODUCTION}

An estimated 75 000-100 $000 \mathrm{~kg}$ of uranitur was expendod during conventional explosive tests at several los Alamos Scientific Laboratory (LASL) testing areas during 1949-1970. Of this, about 35 000$45000 \mathrm{~kg}$ of natural uranium was used during 1949-1954, and $40000-50000 \mathrm{~kg}$ of de.pleted uranitum was used during 1955-1970."

Natural uranium is of concern because of its radioactivity. However, the principal concern about depleted uranium is the effect of its chemical toxicity and weaporsassociated pyrophoric properties on terrestrial ecosystems.

This report describea preliminary findings on the ecological effect of natural and depleted uranium diapersed during explosives tests at selected LASL areas, and gives analytical results on solls from Egin Air Force Base (EAFB), Florida, firing ranges slightly contaminated during testing of depleted uranium penetrators. objertives of this preliminary report are to: 
1. Describe the uranium concentrations in soil near the targets used in testing uranium projectiles at EAFB:

2. Describe the uranium conzentrations and distribution at LASL testing sites, determined by analyzing soil and biota samples;

3. Describe small mamnal populations ana vegetarive communities at selected LASL firing siles and surrounding areas exposed to various amounts and physical forms of uranitr:;

4. Analyze plant and invertebrate soil communities associated with various amounts of uranium at LASL testing sites to determine responses to uranium's chemical toxicity; and,

5. Compare results from studies of uranium in LASL's semiarid envirorment and EAFB's semitropical environment as a function of uranium concentration, to provide a basis for broader extrapolation to use of depleted uranium munitions.

At LASL this initial study consisted af describing the ecosystem and determining the uranium concentrations in soils, plants, snd small mamal communities at the selecttd firing sites to provide an integrated jicture of food chain transmission potenlial. Maureen Romine of New Mexico Highlands university compiled and evaluated -egetative canopy coverage data on the LASL firing sites, to compare plant community esponses to various uranium concentrations in the soil. Donald $c$. Lowrie of Santa ie, New Mexico, identified and evaluated nverteorate soil populations.

\section{THE LASL AREA}

LASL consists of 27000 acres in north-central New Mexico on the Pajarito l'lateau, on the eastern slopes of the Jerlez Mountains west of the Rio Grande

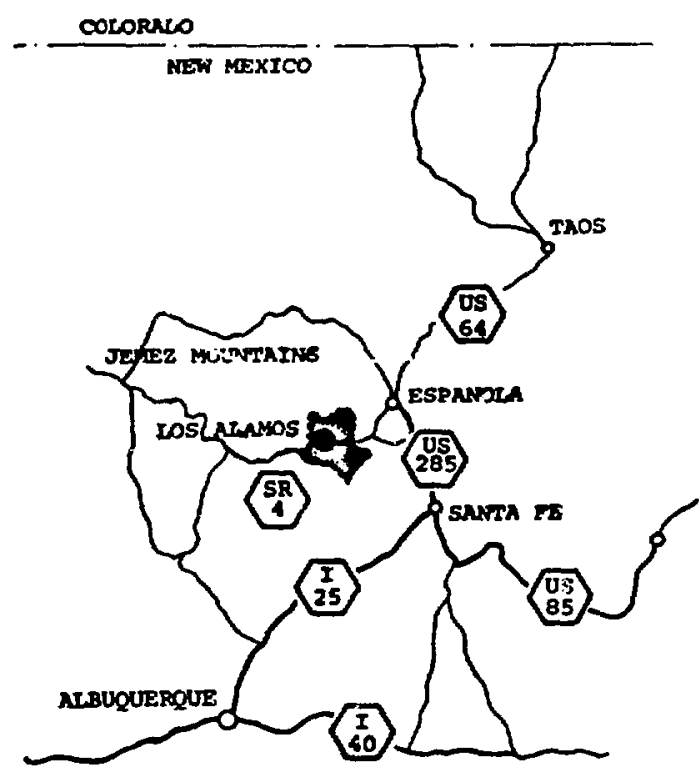

Fig. 1. North-central New Mexico.

(Fig. 1). A brief description of the area, adapted from Hanson, ${ }^{2}$ is as follows.

"The general area has an east-west elevational gradient of $1500 \mathrm{~m}$ within 25 airline $\mathrm{km}$ from $1700 \mathrm{~m}$ above sea level at the Rio Grande to $3200 \mathrm{~m}$ in the Jemez Mountains. IASL is located atop the mesas at about 2000 2600 m. Three Life zones (Merriam, 1894) are represented: upper Sonoran, 1700-1950 m; Transitional, 1950$2400 \mathrm{~m}$; and Canadian, 2400-3200 m. Sheer cliffs, steep forested slopes, and flat mesas and canyon bottoms within each zone cuntain diversified habitats and many ecotones, or transition areas of overlapping plant and animal communities. This "edge effect" is heightened by the east-west topographic orientation that produces great differences in solar input and soil moisture between north and south slopes. "The climate is semiarid, with approximately $46 \mathrm{~cm}$ of annual precipitation. Nearly 758 of this occurs during spectacular May-October thundershowers and accounts for much of the canyor erosion. 


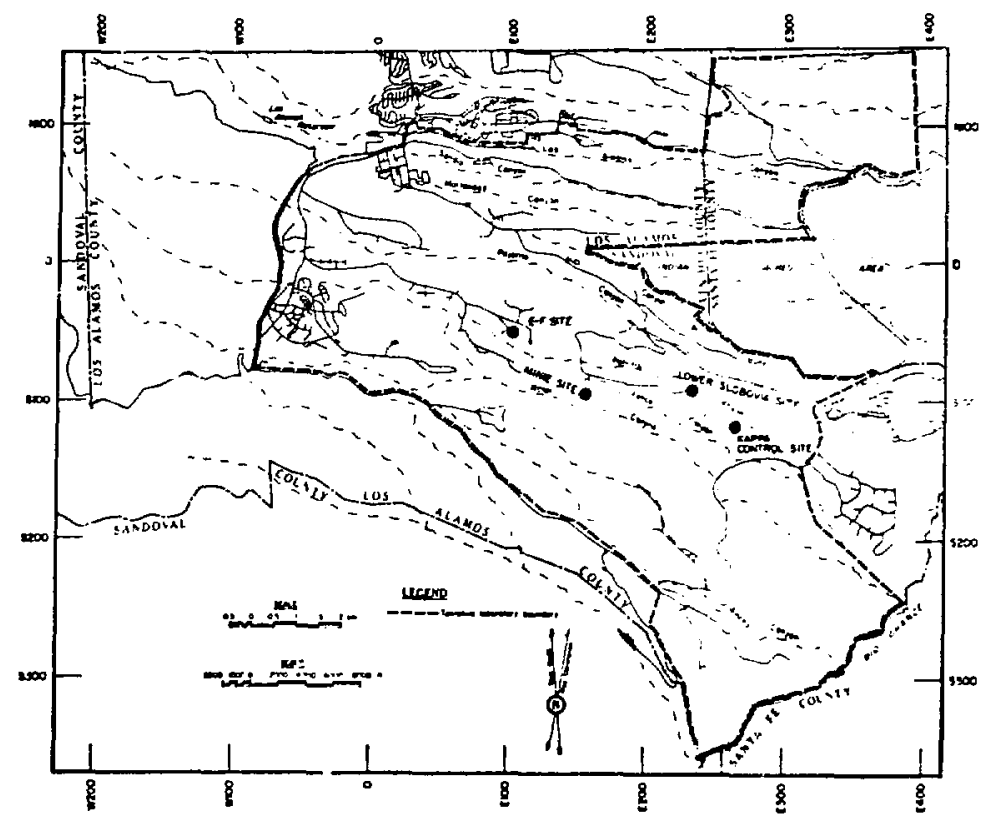

Fig. 2. The LASL area and study sites.

"The area soils have not, for the most part, been characterized. They are forming in basic igneous materials, and there is a generaily repeated soil pattern directly related to landscape features and the effects of climate, time, topography, parent material, and vegetation."

Los Alamos area fauna includes 4 species of fish, 9 of reptiles, 187 of birds, and 37 of mamnals. Plants include 139 species of 37 families.

III. LASL URANIUM STUDY SITES

Four LASL sites (Fig. 2) were chosen for this study in October 1974. Three, presently used as firing sites, were selected on the basis of use history. The fourth was a control area. E-F Site at $2190-m$ elevation was selected as having potentially high uranium concentrations; there are large pleces of depleted uranium scattered throughout the site. Minie site at $2100 \mathrm{~m}$ was chosen as having potentially moderate uranium concentrations, anc Lower Slobovia (LS) at $2000 \mathrm{~m}$ was chosen as a potentially low concentration site. The explosives tests at Minieand LS Sites scattered smaller particles than those at E-F site. Control site was also at approximately 2000-m elevation. Each study site measured 500 by $500 \mathrm{~m}$.

All firing sites evidence depleted urantum's pyrophoric properties and resultanc explosives properties, in that the overstory vegetation surrourding them has been burned and is now in rarious recovery stages. Appendix A contains photographs of the study sites: the aerial photographs are enlarged from a scale of 1:6000.

To study the selected sites more intensively, we eliminated Minie Site after the November sampling, because species composition of vegetation and small mammals there and at Lower Slobovia was similir.

IV. METHODS

A. Sample Collection

Soil, vegetation, and rodents were collected at LASL for uranium analyses. 


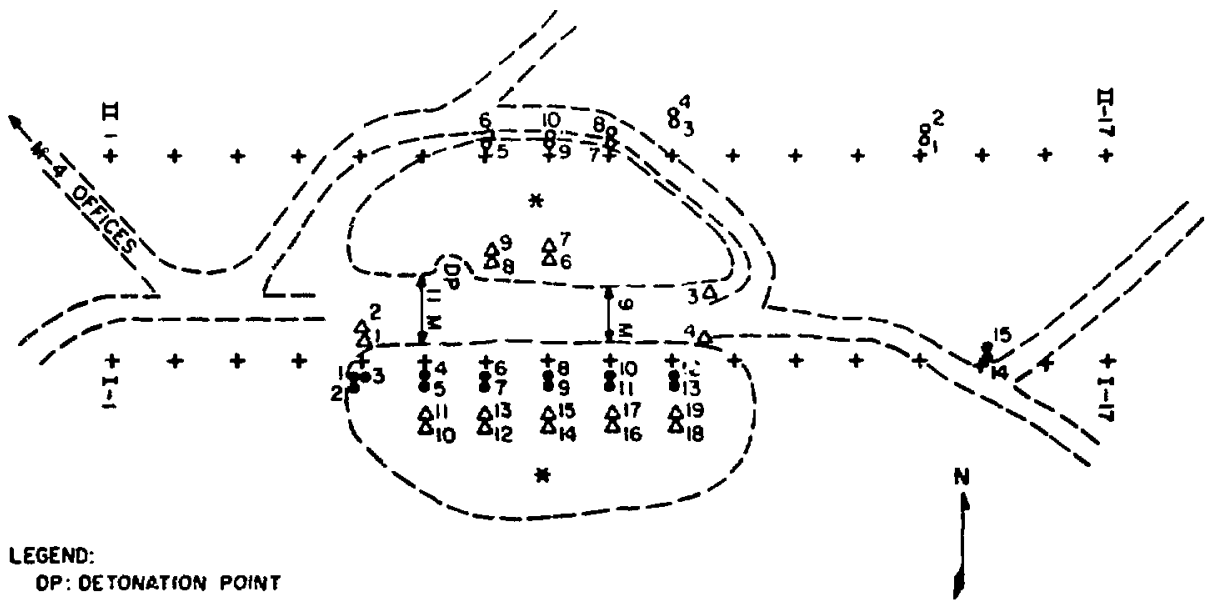

OP: OE TONATION POINT

+ trapping stations at 10-m intervals

- group I soll sampling jites

- group il soll sampling sites

a - eroup il soll sampling sites

* pelaks of firing mounos

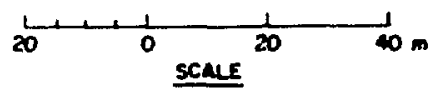

Fig. 3. Map of E-F study site, showing soil and small mamal collection sites.
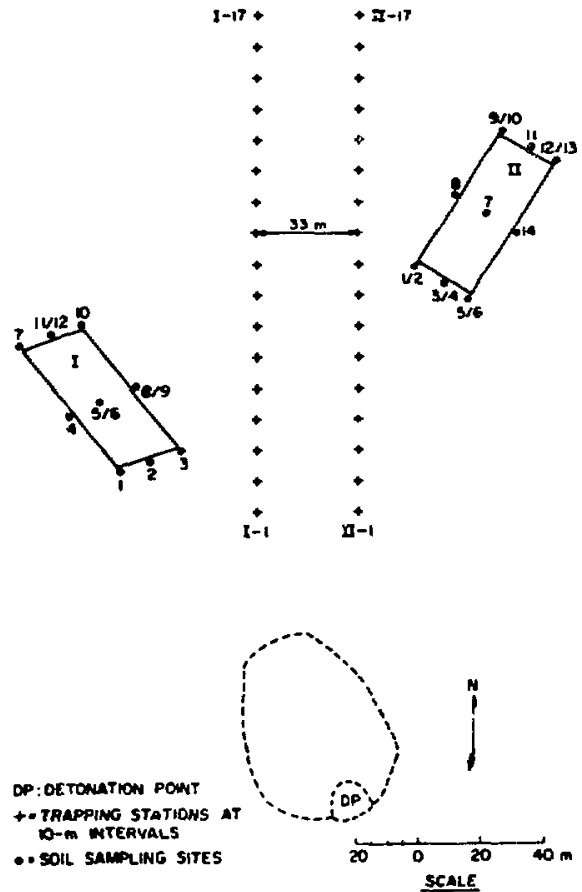

Fig. 4. Map of Kappa Lower Slobevia site, showing location of soil and small manmal collection sites.
EAFB soil samples were collected by Air Force personnel and sent to LASL for analyses.

LASL soil samples collected in November 1974 and EAFB samples collected at about the same time were gathered using similar spatula techniques. The samples were 1- by 1 - by $0.5-\mathrm{cm}^{3}$ units, usually two per location. Each consisted of an upper 0- to 5- or a lower 5- to 10-cm horizon taken 50 as to avoid cross-contamination. EAFB soils consisted of 50 samples from ADTC Range C 74L. Samplea were collected from the base of the target butt and 60 , 120,180 , and $240 \mathrm{ft} 118,37,55$, and 73 m) from it. Control samples also were collected from a gitable nearby location.

LASL soil samples were collected from 6-10 locations on a 500-m transect and also adjacent to vegetation, small mamal, and soil invertebrate sampling sites. Soil sampling locations at E-F and LS sites are shown in Figs. 3 and 4. Samples collected in June 1975 were $1-\mathrm{dm}^{3}$ units taken at similar sites. 


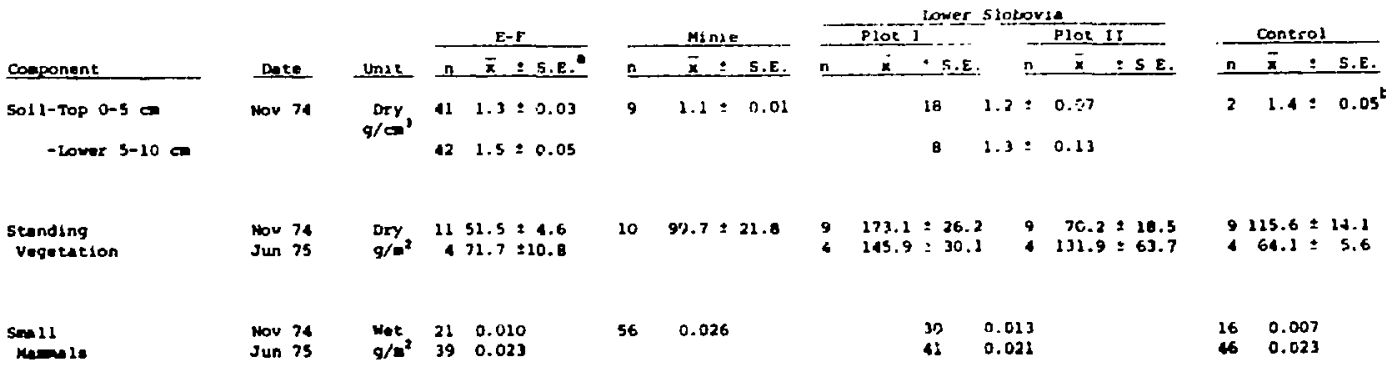

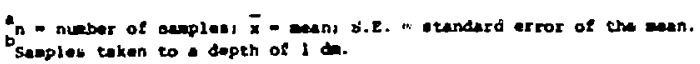

LASL vegetation samples were collected from $1-m^{2}$ plots. All standing vegetation within each plot was clipped at yround level, and all species were composited as one sample for analyses. Loss of the first set of vegetation samples collected in November 1974 during chemical analysig necessitated resampling in February 1975. A corresponding set of samples were collected in June 1975.

All snap-trapped rodents collected in November 1974 and random individuals sacrificed during live-trapping in June 1975 were carefully dissected to avoid crosscontaminating the soft tissues with hair or soil from the pelt. Tissues collected in November were divided into three groups: the polt, carcass (skeleton, skeletal muscle, and internal organs), and the gastrointestinal (GI) contents. The GI system tissues were discarded. June rodent samples were further subdivided to permit determination of uranium concentrations in individual organs. Tissues and organs analyzed included the pelt, muscle, bone, lungs, ard liver. In pocket gophers, the GI contents and kidneys also were analyzed.

Table I gives soil and vegetation mass estimates and a minimal estimate for small mamnals. The term "minimal" is used because not all small mammals were removed from any area. Soil $\left(9 / \mathrm{cm}^{3}\right)$ and vegetation $\left(g / m^{2}\right)$ mass estimates are expressed as dry weights; small mammal $\left(\mathrm{g} / \mathrm{m}^{2}\right)$ estimates, as wet carcass weight. A mean vegetation mass estirnate for both LS plots would be comparable to that for Minie Site. November 1974 simall mammal biomass estinates were greatest at the firing sites and lowest at Cortrol sice; however, no such difference was found in the June i975 results. Descriptive analyses of plant communities subjected to long-term uranium deposition were performed. These analyses included determination of species diversity, canopy coverage, frequency, and density of understory plants at the four study sites; all sites are located in ponderosa pine/ piñon-juniper ecotones.

Three vegetation test plots and one control plot, each 20 by $50 \mathrm{~m}$ with zero slope, were established and permanently marked. One test plot was approximately $100 \mathrm{~m}$ southeast of the firing mound at Minie site. The other two were approximately $100 \mathrm{~m}$ northeast (plot 1) and $100 \mathrm{~m}$ southeast iplot 2) of the Lower Slobovia firing mound. The control site plot 
was $0.5 \mathrm{~km}$ southeast of the Ls firing mound. All four plots were in the same vegetation type.

Vegetation test and control lines were established at E-F Sire. All test lines were on a man-made hill directly south of the deconation point. Test line 1 was on the north-facing slope, and Test Iine 2 was on the south-facing slope, both $3 \mathrm{~m}$ up Erom the base of the hill, and both $40 \mathrm{~m}$ long. Test Line 3 ran north to south over the cop of the hill and was $30 \mathrm{~m}$ long. Control Line 1 (zero slope and $40 \mathrm{~m}$ Long) was southwest of the firing mound. Fontrol Lines 2 (south-facing slope and 46 r. long) and 3 (east-facing slope and $50 \mathrm{~m}$ Jong) were south and southeast, respectively, of the firing mound.

Canopy coverage (i coverage/plot). species frequency ( 8 of plots containing species), and plant density (rooted plants/ plot) were determined using forty 20 - by $50-\mathrm{cm}$ sample plots at $1-\mathrm{m}$ intervais outside one 5n-m side of each test and control plot and along test and control 1 ines at $E-F$ Site, except for Test Line 3 where 30 gample plots kere used for canopy coverage analysis according to Daubenmire's method. ${ }^{3}$ These lines of small plots vere designated "Test Line" at Minie Site, Test Lines $I$ and II at LS, and Control Line at control isite. Vegetative sample plots were so placed as to avoid disturbing the main plots. Grass densities were not determined. All values giver are mean values.

scientific names are from sarrington." and common names are from the Forest Ser... vice checklist. 5

B. Sample Analyses Soil samples were oven-dried at $100^{\circ} \mathrm{C}$ for $24 \mathrm{~h}$, and the dry weight was recorded. The sample was then passed through a 6-mm screen to remove large pieces of rock and uranium, and the fine fraction was ground to less than 100 mesh in a pulverizer (Bico Pulverizer iYpe UA) and thoroughly blended to provide a homogenous sample. Replirates were prepared at the same $\tau$ ime. An approximately 5-g aliquot of the pulverized soil and the larger pleces of material were then leached separately in a hydrofluoric and nitric acid solution. The leachates were combined and analyzed for total uranium (natural uranium plus depleted uranium) by a standard fluorometric technique, 6,7 Results were expressed in microgramg of uranium per gram of total sample, equivalent to parts per million. Vegetation samples were oven-dried at $100^{\circ} \mathrm{C}$ for $24 \mathrm{~h}$ to determine standard dry weight and then burned in a muffle furnace at. $450^{\circ} \mathrm{C}$ until a white ash was obtained. The ash was dissolved in $7.2 \mathrm{~N} \mathrm{HNO}_{3}$, and an aliquot was analyzed. Animal samples also were oven-dried at $100^{\circ} \mathrm{C}$ for $24 \mathrm{~h}$ and then dissolved in $7.2 \mathrm{~N}^{\mathrm{NNO}} \mathrm{H}_{3}$ and $\mathrm{H}_{2} \mathrm{O}_{2}$, and an aliquot was analyzed.

Replicate aliquots of 100 soil samples and biotic sample leachates from the November sampling, with blanks and standards, were sent to Eberline Instrument Company in Albuquerque for comparative uranium analysis. Replicates of all 50 EAF3 soil samples were included.

Detection limits of LASL analyses made with the fluorometric technique used were $0.3 \mathrm{ug}$ of cranium per $g$ of sample of rcdents or vegetation, with \pm 78 standard deviation due to analytical error. The procedure gave an analytical error of 1008 for samples that contained $<0.3 \mathrm{ug}$ of uran$i \mathrm{im}$. The detection limit for soils was $0.6 \mathrm{~kg}$ of uranium per $g$ of sample, with a standard deviation of \pm 108 .

c. Comparison of Eber 1 ine and LASL Chemical Analyses of Soil Uranium

Aliquots of 50 homgenized soil samples from EAFB, and 50 similar aliquots of LASL soil samples, with suitable blind replicates and standards, were analyzed by Eberline Instrument Company to provide interlaboratory comparison of uranium results. The LASL soil samples were selected from 120 taken in November 1974 and 21 taken in June 1975. Both Eberline and LASL used acid-leach digestion followed by 
men 4

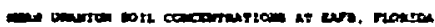

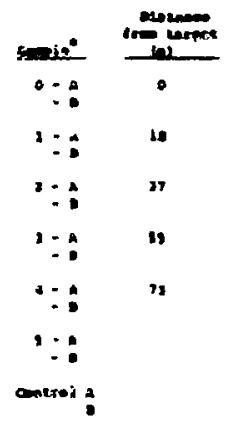

\begin{tabular}{|c|c|}
\hline 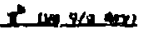 & 도 \\
\hline $\begin{array}{r}\text { 91.0 } \\
98.0\end{array}$ & $\begin{array}{l}0.20 \\
0.0\end{array}$ \\
\hline m.j & $\begin{array}{l}3.20 \\
3.20\end{array}$ \\
\hline $\begin{array}{l}7.0 \\
1.2\end{array}$ & $\begin{array}{l}2.30 \\
2.22\end{array}$ \\
\hline $\begin{array}{l}3.2 \\
2.0\end{array}$ & $\begin{array}{l}0.67 \\
1.45\end{array}$ \\
\hline $\begin{array}{l}0.3 \\
2.3\end{array}$ & $\begin{array}{l}0.10 \\
0.31\end{array}$ \\
\hline $\begin{array}{l}\text { o.o. } \\
\text { c.e. }\end{array}$ & 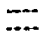 \\
\hline 6.e & $\cdots$ \\
\hline
\end{tabular}

\begin{tabular}{|c|c|}
\hline El & 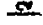 \\
\hline $\begin{array}{r}18.0 \\
28.0\end{array}$ & 0.4 \\
\hline 13.2 & $\begin{array}{l}2.14 \\
2.26\end{array}$ \\
\hline J.4 & $\begin{array}{l}0.41 \\
0.13\end{array}$ \\
\hline $\begin{array}{l}2.3 \\
0.2\end{array}$ & $\begin{array}{l}0.14 \\
0.11\end{array}$ \\
\hline $\begin{array}{l}0.7 \\
0.1\end{array}$ & $\begin{array}{l}0.80 \\
0.12\end{array}$ \\
\hline $\begin{array}{l}0.7 \\
0.3\end{array}$ & $=$ \\
\hline $\begin{array}{l}0.2 \\
0.1\end{array}$ & $\cdots$ \\
\hline
\end{tabular}

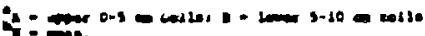

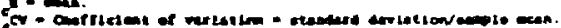

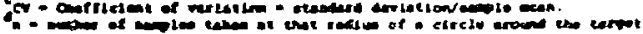

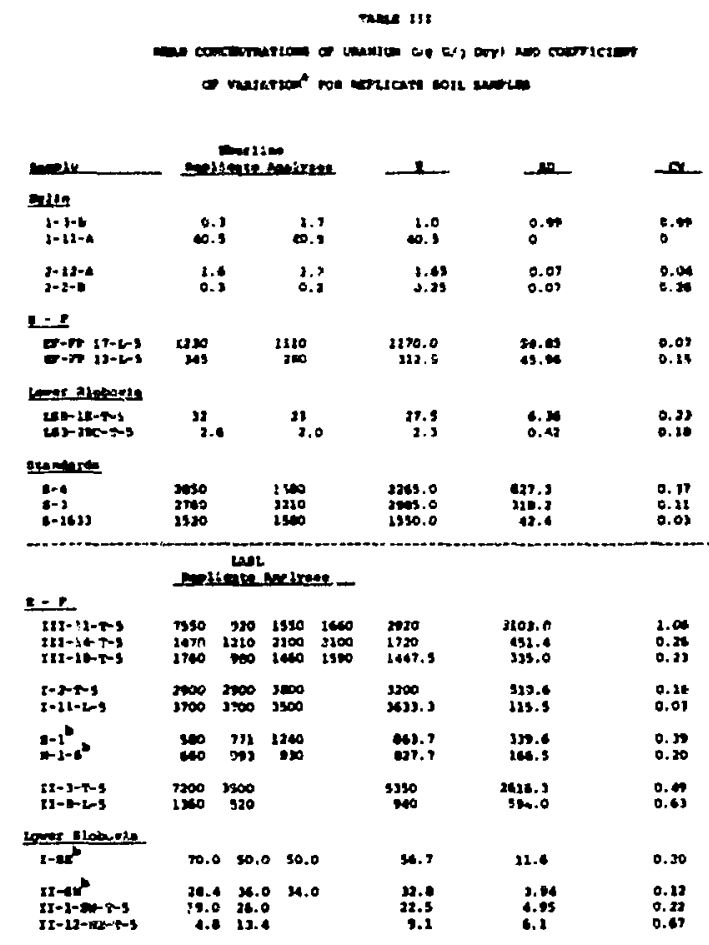

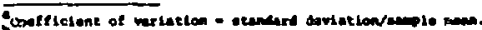

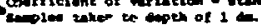

fluorometric analyois. Results for individual soil samples are given in Appendix $B$. Eberline and LASL values for EAFB soll aliquota are compared in Table II. The usl values were generally higher than Eberline's and more variable. Eberline's coefficient of variation (CV) is 11-1168, compared to LASL's 20-200z, and individual values are evenly distrikuted throughout these ranges. This variation can be attributed partly to nonuniform dispersion from the target butt of uranium in a variety of particle sizes; soil samples from areas of lower urantum deposition varied less.

both Eberline and LhSL analyzed replicate 5-q allquots of individual homogenized soil samples to evaluate the variability of their respective procedures. Eberline's results from 11 such samples, including three standards, are prasented in Table III. The $C V$ was $0-99 \%$; 11 but one value being below 378. Standard values showed CV's of 3, 11, and 37\%, or about the same as those for replicates.

LASL analyzed replicates of 13 individual homogenized samples in groups of 4 . 3 , and 2 samples each (Table III). CV's were 3-1068, all but four values being $<398$. Three of the most variable values were in replicates from E-F Site, where soils contoined the highest uranium concentrations. Quality control data for WASI analyses are presented in Appendir $C$.

\section{v. RESULTS AND DISCUSSION \\ A. Uranium Concentrations in EAFB Soil Samples \\ The maximum uranium concentrations in} the Eglin soil samplea that IASL analyzed were in the upper $0-5 \mathrm{~cm}$ of soil from the base of the target butt (Table II). However, there seemed to be no appreciable uranium penetration or migration into the soil; concentrations in the lower $5-10 \mathrm{~cm}$ were only about 48 of those in the top $5 \mathrm{~cm}$. A similar relationship with depth was observed $18 \mathrm{~m}$ from the target butt, where the 5- to 10-cm proriles contained $<108$ of 


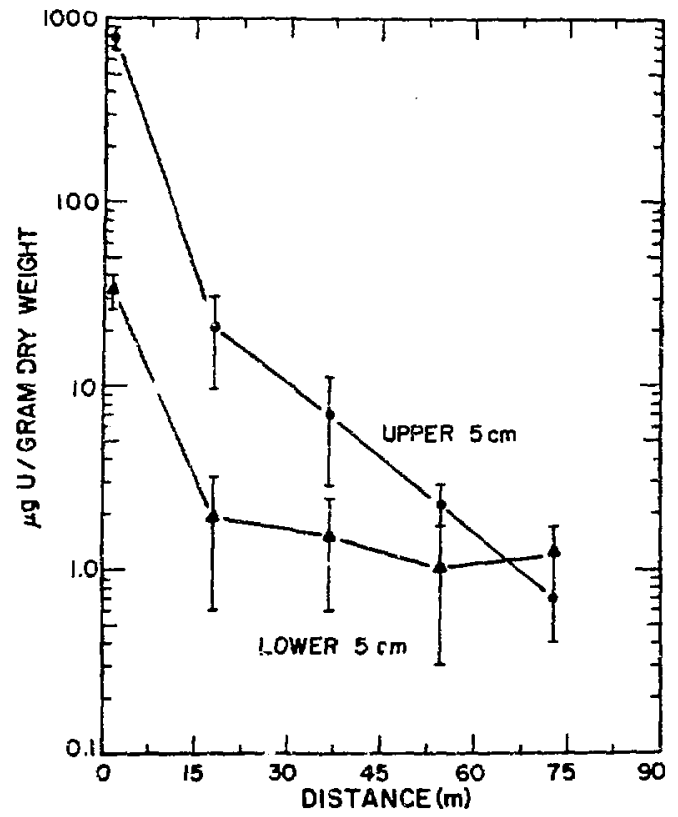

Fig. 5 Mean uranium concentrations ( \pm 1 S.E.) in soil at various distances frcm target butts at EAFB in November 1974.

the uranium in the samples. The uranium concentrations in soil $>20 \mathrm{~m}$ from the target butt averaged $2.3 \pm 1.0$ (S.E.) $\mu \mathrm{g} / \mathrm{g}$ (= ppm), and in almost all instances were lower than control values at both depths which averaged $3.9 \pm 0.9 \mu \mathrm{g} / \mathrm{g}$, but were not significantly different $(P \leq 0.05)$ * The results, graphically presented in Fig. 5 , demonstrate the observed relationship of uranium concentrations in upper and lower soil horizons.

5. Uranium Concentrations in LASL soil Samples

The uranium concentrations in LASL soils collected in November 1974 and June 1975 are shown in Tables IV and $V$, respectively.

Uranium concentrations in E-F. Site soils taken at botr sampling times averaged

$\star \mathrm{p}=$ probability of rejecting a null hypothesis.
40-100 iimes higher than those in soils from the other study areas, reflecting past use histories of the respective sites. The E-F rite explosive tests apparently involved about 39 times more uranium than tests at all the other sites combined.

Uranium in $\mathrm{E}-\mathrm{F}$ sils averagea about 2400 and $1600 \mu \mathrm{g} / \mathrm{g}$ at $0-$ to $5-$ and $5-$ to 10-sm depths. Differences between upper and lower depths although not statistically significant ( $P \leq 0.05$ ), reflected vertical movement of the uranium into the soil. The mechanisms for this movement could be erosion processes, mechanical disturbances, and/or penetration of uranium fragments into the soil during the explosive tests. Uranium concentrations in the top $5 \mathrm{~cm}$ of Lower Slobovia soils were significantly higher $(\mathrm{P} \leq 0.05)$, than those at $5-10 \mathrm{~cm}$. The vertical concentration gradient contrasts with that observed at E-F site although both areas were used for explosive testing for about the same length of time.

Important differences between $E-F$ site tests and those at the other sites may partly explain the observed uranium distribution patterns. Explosive tests at E-F site deposited relatively large fragments: particlos range from about $2 \mathrm{~mm}$ to several cm in diemeter, Tests at Lower slobovia produced consistently smaller dis persed uranium p:-ticle size ranges.

The greater particle size range at $E-F$ site is apparent in the variability of uranium concentrations in its soil. The $C V$ in $\mathrm{E}-\mathrm{F}$ soils ranged from 1.54 in the surface $5 \mathrm{~cm}$ to 2.85 in the $5-$ to $10-\mathrm{cm}$ profiles, reflecting considerable inhomogeneity of the uranium in the soil. At least some of this extreme variation comes from samples containing relatively large pieces of uranium.

Although variability in soil uranium at the other areas was also great (CV's of.. 0.93-1.7), it averaged somewhat less than at E-F Site.

The lesser variation in Minie and IS site soils which is indicative of relatively 
TABLE IV

NATURAL AND DEPTETED URANIUM CONCENTRATIONS

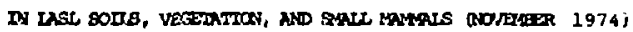

$(\mu g / g$ dry)

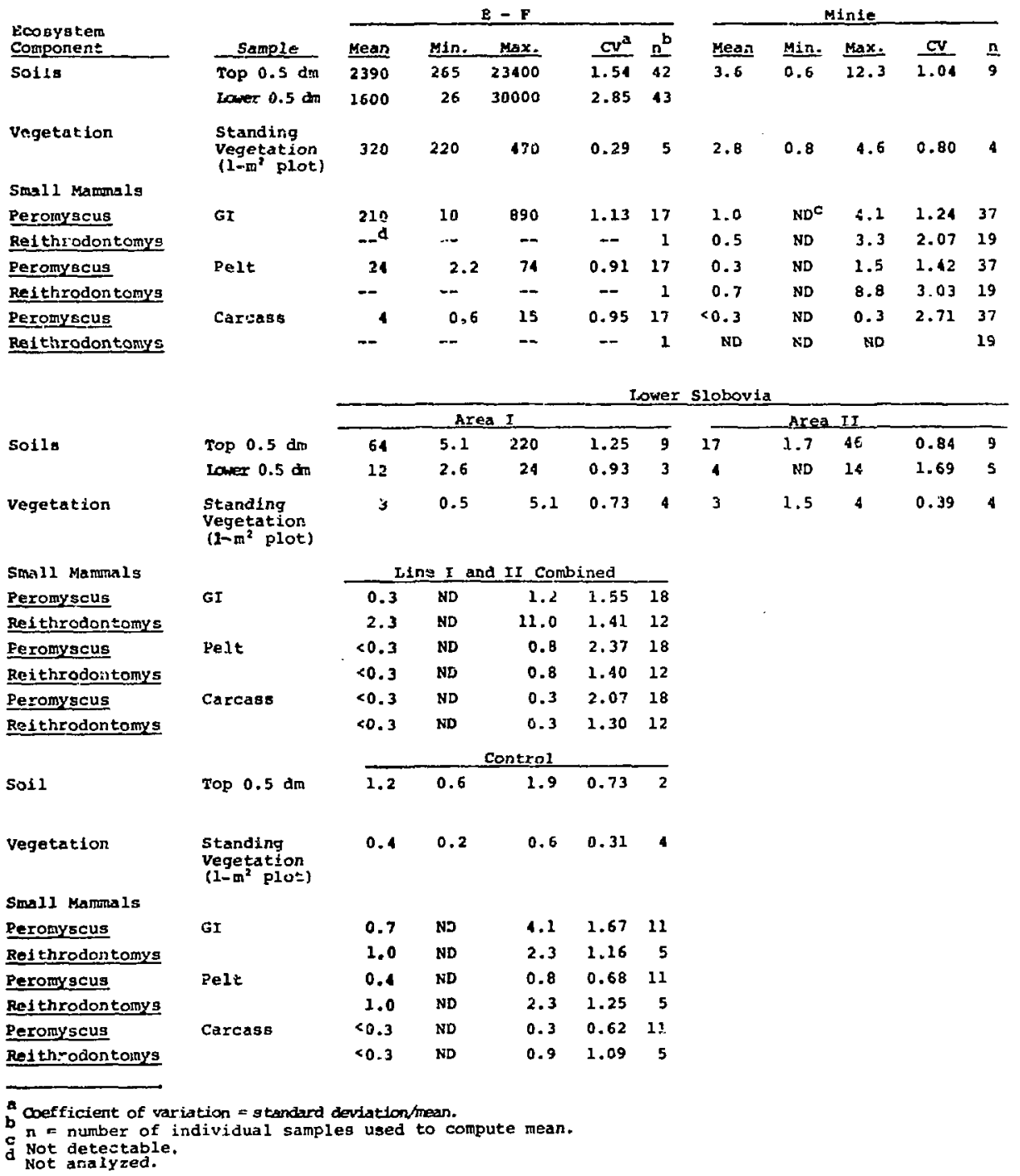


MTRRA AND DEPLETED LPANILA CONCDNTRATION

IN USL SOILS, VEEETATION, AND SNLL MAYMLS (JNE, 1975) (inglo drr)

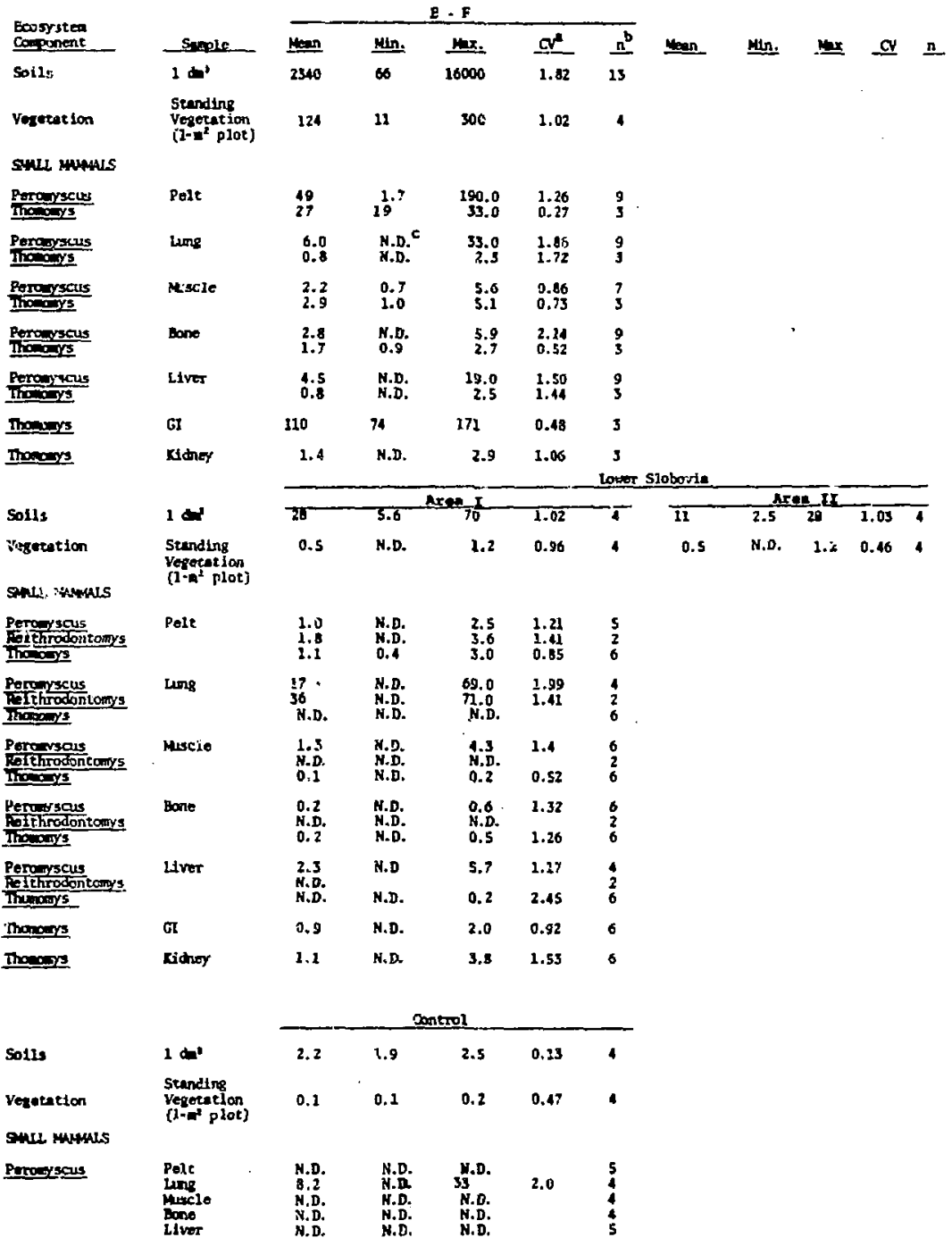

Coeffletent of veriation - 5tanderd devistion/mean.

h - number of individu* tiles used to conpute bean.

Gibe detertoblc. 
Sreater homogeneity of soil uranium is consistent with our knowledge of the particle sizes generated during explosive test.s there. Neither site exhibited the mechanical disturbances of the soils which were comnon at E-F site. Uranium movement into the soil was probably governed by weathering processes and burrowing by small mammals, rather than explosive force.

Elevated uranium content was detected in soils $90 \mathrm{~m}$ from the E-F detonation points and $225 \mathrm{~m}$ from the LS point. These are the greatest distances at which samples were raken, not necessarily the greatest at which uranium debris was deposited.

Soil collected northwest of the Lower Slobovia detonation point (Area I) in both sampling periods exhibited three to four times higher uranium concentrations in the upper and lower 0.5 -dm samples (Tables IV and $V$ ) than soil from the northeast quadrant (Area II). These distributions apparently reflect local wind direction patterns.

Background concentrations of natural uranium at Control site ranged from 0.6 to $2.5 \mathrm{\mu g} / \mathrm{g}$, slightly higher than those reported $(0.16-1.24$, averaging 0.58$)$ in northern New Mexico. 8

\section{c. Uranium Concentrations in LASL Biota}

The highest uranium concentrations in

LASI biota (Tables IV and $V$ ) were found in samples from E-F site, whose soil aiso had the highest concentrations. Vegetation collected in November 1974 and February 1975 was standing dead vegetation that had been exposed to uraniumcontaminated soil for at least 6 months. No explosive tests involving uranium had been conducted at E-F site for more than 1 yr at that time. Vegetation sampled in June 1975 was late spring growth, mainly green material that had been only briefly axposed to external uranium deposition or uptake. Observed concentration ratios (plant $U \div$ soil $U$ ), presented in Table VI, show a general decrease in the new growth. The high ratios in the November samples
TABLE YI

AATIUS OF PLANT: SOIL JRANIUM CONCENTRATIONS IN FALL AND SPRING SAMPLES

\begin{tabular}{|c|c|c|c|}
\hline Location & Sameling & Period & $\begin{array}{l}\text { Plant U } \\
\text { Soid U }\end{array}$ \\
\hline$E-\mathbf{F}$ & $\begin{array}{l}\text { Hovember } \\
\text { June }\end{array}$ & $\begin{array}{l}2974 \\
1975\end{array}$ & $\begin{array}{l}0.08 \\
0.05\end{array}$ \\
\hline $\begin{array}{l}\text { Lower Slobovia } \\
\text { Area I }\end{array}$ & $\begin{array}{l}\text { Novenuber } \\
\text { June }\end{array}$ & $\begin{array}{l}1974 \\
1975\end{array}$ & $\begin{array}{l}0.04 \\
0.02\end{array}$ \\
\hline $\begin{array}{l}\text { Lower Slobovia } \\
\text { Area II }\end{array}$ & $\begin{array}{l}\text { November } \\
\text { June }\end{array}$ & $\begin{array}{l}2974 \\
2.975\end{array}$ & $\begin{array}{l}0.13 \\
0.04\end{array}$ \\
\hline Control & $\begin{array}{l}\text { Norember } \\
\text { June }\end{array}$ & $\begin{array}{l}1974 \\
1975\end{array}$ & $\begin{array}{l}0.34 \\
0.06\end{array}$ \\
\hline
\end{tabular}

from both Lower Slubovia Area II and Control Site are attributable to high $U$ and DU conceltrations in vegetation at that time. These results were consistent with Cannon's 9 in which "uranium indicator" plants had ratios of $0.01-1.0$. This relationship should be studied further to evaluate the importance of resuspension in field studies of plant:soil ratios.

During the June sampling, we tried to determine the uranium concentrations within plant roots, compared to uranium particles that were adsorbed on the root surfaces, and to determine relative concentrations in dominant plant species. One-dm ${ }^{2}$ subplots were established $1 \mathrm{~m}$ from the $1-\mathrm{m}^{2}$ vegetation sampling plots, and the vegetation was totally removed. The intact soil was then removed to a depth of $1 \mathrm{dm}$, yielding a $1-\mathrm{dm}^{3}$ sample with plant roots in place. This material was then passed through a 2-mm-mesh sieve to separate soil from roots. The soil was treated as previously described; the roots were washed in a sonic bath of distilled water for $2-3 \mathrm{~min}$, rinsed with distiller. water, microscopically $\in$ xamined for adhering particulates, and then analyzed like a vegetation sample. The above-ground parts of the plants removed from the $1-\mathrm{cm}^{2}$ area were analyzed similarly. Results are presented in Table VII. Uranium concentrations in E-F site soils obtained under these special conditions were higher than those shown elsewhere in this report because of the influence of a single sample that contained $16000 \mathrm{\mu g} / \mathrm{g}$ of uranium. Soils from LS Area I contained less uranium than indicated in Table IV, reflecting the variable 
TABLE VII

MEAN URANIJM CONCENTRATIONS ( $\mu g / g$ drY) IN AERIAL PARTS, ROJTS, AND ROOTING IAYER SOILS OF SELECTED VEGETATION

Location
$E-F$
Lower Slobovia
Area I
Lower Slobovia
Area II
Control

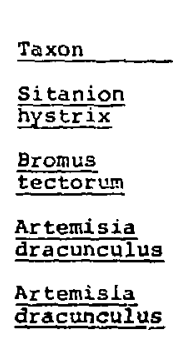

\begin{tabular}{|c|c|c|}
\hline$\overline{\mathbf{x}}$ & $\mathrm{cV}$ & $n$ \\
\hline 1.0 & 0.98 & 4 \\
\hline 2.7 & 1.06 & 4 \\
\hline 0.7 & 0.75 & 4 \\
\hline 0.4 & 1.26 & 4 \\
\hline
\end{tabular}

\begin{tabular}{|c|c|c|}
\hline \multicolumn{3}{|c|}{ Roots } \\
\hline$\overline{\boldsymbol{x}}$ & $\mathrm{cV}$ & $n$ \\
\hline 1370 & 1.03 & 4 \\
\hline 16.6 & 0.29 & 4 \\
\hline 2.0 & 1.34 & 4 \\
\hline 0.1 & 0.54 & 4 \\
\hline
\end{tabular}

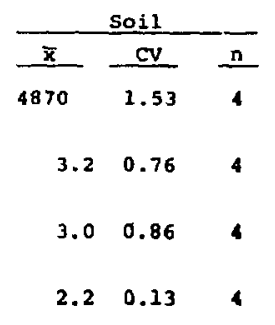

discribution of uranium in these study areas. Root:soil uranium ratios were highly variable: 0.28 at E-F Site; 5.26 at LS Area I; 0.64 at LS Area II; and 0.05 at Control site. At least part of this variability was caused by several small particles of soil and, presumably, uranium adhering to roots; the particles were found by microscopic examination. Furthermore, uranium colloids would not be seen but may well have been sorbed on the root surface. This fact further complicated the differentiation of "in" vs "on" uranium components in plant roots, despite efforts to separate the two. Roots of cheatgrass (Bromus tectorum) at LS Area I contained a greater uranium concentration than did the surrounding soil, probably reflecting higher concentrations in fine particles that adhered to roots; and aerial parts of grasses at E-F and Area I contained higher concentrations than did associated forbs, possibly owing to surface area and particle size differences.

June trapping samples suggested similar trends in small mammals. Jranium concentrations in pelts of E-F and LS Peromyscus were higher in June than in November by factors of 2 and 10, respectively. Concentrations in Reithrodontomys pelts were also elevated by a factor of 10 at LS Site. The GI contents of Thomomys analyzed in June also showed lower concentrations than similar Peromyscus and Reithrodontomys samples analyzed in November. These differences were attributed to drier soils and possible soil texture differences between LS Site and E-F Site, which enhanced resuspension contamination.

of the small mammal internal tissues analyzed (muscle, bone, liver, and kidney), Peromyscus livers had the highest mean uranium concentrations. Results of Thomomys internal tissue analyses are not clear. However, the data suggest that mean uranium concentrations at E-F site were greater in Peromyscus than in Thornomys, although not significantly so. A similar case may apply to LS site, where differences among animal specieg were most obvious in comparisons of pelt, lung, and liver samples. We expect future analyjes of GI contents also to bear out this relationship. The subterranean activities of pocket gophers (Thomomys) suggest that, although they are in close contact with elevated uranium concentrations in soil, the top few millimeters of soil contain the more resuspendable uranium fraction. Therefore, the surface activities and different food preferences of deer mice isoroliyscus) cause their greater exposure to particulate uranium.

The variation of uranium concentration in almost all biotic samples was generally greater than that in s:oll samples, and it was attributed to biological magnification of the biota's heterogeneous exposures. 
In all three species of small mammals sampled at all sites, the GI contents had the highest mean uranium concentrations; lesser amounts were found in pelts, carcasses, and lurigs. Lungs analyzed as separate samples in June contained higher concentrations than did carcasses. Samples from $E-F$ site genelally had higher mean uranium concentrations than those from other sitas, except for high concentrations in Peromyscus and Reithrodontomys lungs sampled in Tune at IS site. This ranking of values in the tissues suggests that uranium resuspension is important in rodent contamination. Whole carcasses sampled in the fall, which consisted of internal tissues unexposed to external contanination, reflected values found in control animals, again with the exception of E-F site. Small mammal pelts from plutoniumcontaminated areas of the Nevada Test Site had higher plutonium concentrations than GI tract samples, indicating that resuspension also was operant in that situation. 10

VI. BIOTIC SURVEY OF LASL STUDY SITES

A. Plant Community Analysis at the Study Sites

Results of E-F site plant analyses are shown in Table VIII. Three species, Kochia scoparia, Salsola kalí, and Sitanion hystrix were found in at least one sample plot of each test line. K. scoparia had the highest coverage values 140.38 , Line 1; 20.88, Line 2; and 28.38, Line 3). uighest frequency values on Test Line 1 were $\mathrm{K}$. scoparia and $\underline{\mathrm{s}}$. hystrix, both of which scored 72.58. K. Scoparia was most Erequent on Line 3 (B5.08); S. Hystrix and K. scoparia. most frequent on Line 2 (both 73.381 . ‥ gcoparia also showed the greatest density values in sample plots on Test Lines $I$ and 3147.9 and 11.4 plant/plot. respectively). The $\underline{s}$. kali density $(7.6$ plants/plot) was oniy 2.9 plants higher than the $K$. Scoparia value on Line 2. Samplo plots ori control lines yielded 15 species of plants, s. mystrix being the only species common to both test and control lines. The grasses had the highest coverage and frequency values on all control lines. Separate grass species were not analyzed for coverage and frequency. Two sagebrush species, Artemisia cana iv. 7 pl: $3 t s / p l o t$, Lines 1 and 2$)$ and $\mathrm{A}$. dracunculus ( 0.3 plants/plot, Line 3) showed the greatest density.

Plant community data for Minie, LS, and Control sites are shown in Table IX. The sampling design was basically the same as at E-F site, including use of three test $l$ ines and one control Jine along one $50-\mathrm{m}$ side of test or control plots. The single control line functioned for all test lines. Eleven species were found on the Test line at Minie Site; ten species eact: on Test Lines 1 and 2 at Lower slobovia; and nine species on the control line at Control Site. Two species, Artemisia dracunculus and Bahia dissecta, and the grasses, which were handled as a single type, were found on all test and control lines. Fallugia paradoxa, Salsola kali, Chenopodium leptophyllum, Cryptantha fendleri. Erigeron flagellaris, Rhus trilobata, vicia spp.. Ribes cereum, and Physalis spp. were found in sample plots on test, but not control, 1ines. Two species, Castilleja integra and Solanum spp. were found on the control line only. The grasses had the hignest coverage and frecijency values on all test and control lines. $\underline{c}$. fendleri, E. Elagellaris, and grass plants were too numerous for density determinations. bit their coverage and Erequency were Evaluated. Excliding these species, S. kali hid the highest density value 10.6 plants/pjot) on the Test line at Minie site. A. dracunculus was densest on Test Line 1 ( 0.3 plants/plot). Test line 2 (1.5 plant/plot), and the Control site line (1.4 plants/plot).

We attempted to determine whether plant distribution, as reflected by species diversity, canopy coverage, frequency, and dengity, was affected by long-term uranium 
E - F SITE VEGETATION ANALYSES, NOVEMBER 1974

Plant Taxon

Chenopodisces"

Kochta sopparia-Belvedere sumper-cypress

S10ola Kali-pansian thiatio

Compositas

Iragogogn dubius-Saluify

\section{Grainse}

sitanlon matrix-Botelebeinh Squirreltail

Aracardiacese

Phere trilobata-Skunkbueh Surac

Boraginaceace

Oryptantha fendleri-Fendlex cryptanth.

\section{Oapositae}

Artemesia cana-Silver Sagebrush Artemisia dracunculus-Faise Tarragon Segobrum

rrtenisia Erigida-Fringed Sagemrued

Eakia dissecta-Ragleaf Bahia

Chrysopsis villoga-Hairy Goldaster

Gutienrezia sarothrae-Erocm Snakewed

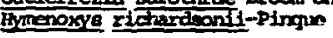

\section{Fogracese}

quercise turbingilo-shrub tuva cak

\section{Graminae}

Legminosae

Luninus argenteus-Silvery upin

Hicis SI, -Vetch

Polygonaceae

Eriogonum racemogum Redroot Erioganum

Frosacease

Cercocarpas montanue-Iria cercocarpu:

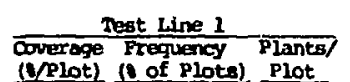
Coverage Frequency Plants
(V/Plot) (1 of plots) Plot

$$
40.3
$$$$
\begin{aligned}
& 72.5 \\
& 52.5
\end{aligned}
$$$$
\begin{array}{r}
47.9 \\
2.2
\end{array}
$$

Coverage Test Line 2

Plot:) (1 of Plots) Plot

\section{8}

60.0
70.0

4.7
7.6

$\begin{array}{r}23.0 \quad 72.5 \\ \text { Control Line 1 } \\ \hline\end{array}$

9.1

Control Line

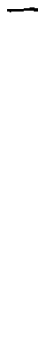

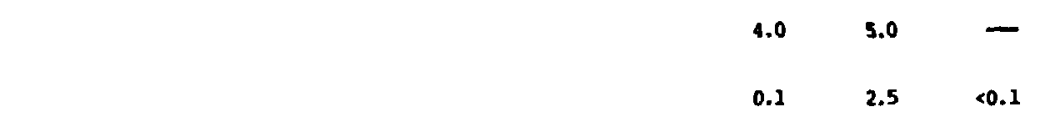

\begin{tabular}{|c|c|c|c|c|c|c|c|c|}
\hline $\begin{array}{l}2.4 \\
1.4\end{array}$ & $\begin{array}{r}35.0 \\
7.5\end{array}$ & $\begin{array}{l}0.7 \\
0.2\end{array}$ & $\begin{array}{l}3.6 \\
3.6\end{array}$ & $\begin{array}{l}25.0 \\
22.5\end{array}$ & $\begin{array}{l}0.6 \\
0.4\end{array}$ & $\begin{array}{l}0.2 \\
4.0\end{array}$ & $\begin{array}{l}10.0 \\
30.0\end{array}$ & $\begin{array}{l}0.1 \\
0.3\end{array}$ \\
\hline $\begin{array}{l}0.1 \\
0.5\end{array}$ & $\begin{array}{l}2.5 \\
7.5\end{array}$ & $\begin{array}{r}<0.1 \\
0.5\end{array}$ & 1.4 & 7.5 & 0.1 & $\begin{array}{l}0.0 \\
2.7 \\
0.9 \\
2.2\end{array}$ & $\begin{array}{r}2.5 \\
12.5 \\
2.5 \\
15.0\end{array}$ & $\begin{array}{r}<0.1 \\
0.2 \\
<0.1 \\
0.2\end{array}$ \\
\hline
\end{tabular}

$\begin{array}{llllll}14.4 & 32.5 & 0.4 & 19.6 & 25.0 & 0.3\end{array}$

benuly name. 
TABLE IX

MINIE, LOWER SLOBOVIA, AND CONTROL SITE VEGETATION ANALYSES, NOVEMBER 1974

Plent Taxon

\section{Anacardiaceata}

Rhus tri lobata-Skunkbush Suanc

Borequinacese

Chenopodiaceae

leotophyllum sineldat coosetoot

Salsolu kali -Russian Thistle

\section{compositae}

Artenis le cana-silver Sagebruah

agon sagabrueh

Aster novaz-angliae-Aater

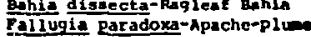

Taraxaci ofticinale-Dandelion

Tregopogon dubiuas-Soleify

\section{Euphorbiscene}

Eupliorble sp.-Euphorbia

regactere

Quercue curbinelle-shrub hive oet

Groninee

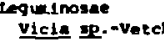

Sexilfragaceae

Nibes cerous-wax currant

scrophular lacese

Contillole integra- Whololeat selntbruen

\section{solaneceos}

Myealie ip. Groundcharry

olent Be - Wightanude
Cryptantha fendler 1-Fendier crypeanthe

Artralsia Griglda-Fringed sogebruth

Hyenoxye riadoxardeoniche-pluan

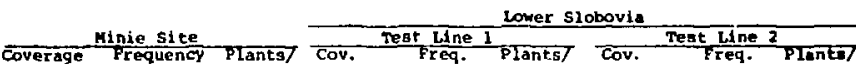

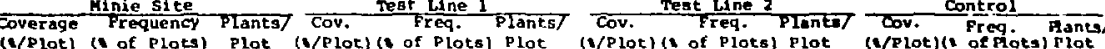

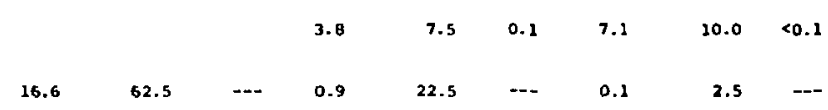

$\begin{array}{rrr}0.1 & 5.0 & <0.1 \\ 15.0 & 40.0 & 0.6\end{array}$

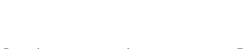

\begin{tabular}{|c|c|c|c|c|c|c|c|c|c|c|c|}
\hline & & & & & & 0.2 & 5.0 & ... & 0.6 & 12.5 & 0.2 \\
\hline 12.5 & 45.0 & 0.5 & 7.1 & $\begin{array}{r}32.5 \\
5.0\end{array}$ & 0.3 & $\begin{array}{r}17.9 \\
2.1\end{array}$ & $\begin{array}{l}62.5 \\
12.5\end{array}$ & $\begin{array}{l}1.5 \\
0.5\end{array}$ & 12.1 & 35.0 & $\begin{array}{l}1.4 \\
0.2\end{array}$ \\
\hline & & & 0.1 & 3.5 & $\cdots$ & 0.1 & 2.5 & - & 0.6 & 5.0 & 0.1 \\
\hline 0.4 & 2.5 & 0.1 & 0.1 & 5.0 & $<0.1$ & 0.4 & 2.5 & 0.1 & 0.2 & 7.5 & 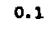 \\
\hline 0.5 & 7.5 & $<0.1$ & 0.4 & 10.0 & 0,1 & 0.1 & 5.0 & $<0,1$ & 2.0 & 17.5 & .2 \\
\hline
\end{tabular}

$0.12 .5 \quad--$

$0.4 \quad 2.5 \quad 0.1$

$0.1 \quad 2.5 \quad \ldots$

$\begin{array}{llllllllllll}27.4 & 85.0 & -- & 63.9 & 100.0 & -\ldots & 33.8 & 97.5 & \ldots- & 46.8 & 90.0 & \ldots \\ 27.4 & 85.0 & -- & 63.9 & 100.0 & \ldots & 33.8 & 87.5 & \ldots & 46.8 & 90.0 & \ldots\end{array}$

Socily nom. 
deposition, and, possibly, to establish uranium indicator plants. Cannon ${ }^{9}$ dia related work on how uranium ore deposits affected vegetation on the colorado Plateau. She noted that plants such as milk-vetch (Astragalus spp.) and Indian ricegrass (Oryzopsis hymenoides) that accumulate selenium and sulfur could be used as indicators of uranium ore deposits. other uranium indicator plants, which were not selenium and sulfur accumulators, were rabbitbrush (Chrysothamnus viscidiflorus), shadscale saltbrush (Atriplex confertilolia), Mormon tea (Ephedra viridis), and grasses, such as galleta (Hilaria jamesii), cheatgrass (Eromus tectorum), and fendler three-awn (Aristida fendleriana). Those plants were found at an altitude of $4900 \mathrm{ft}(1494 \mathrm{~m})$. Studies in areas containing uranium ore on higher mesas in southwestern colorado at altitudes of 6000-8000 ft (1829-2438 m) showed uranium-tolerant vegetation to be predominately juniper (Juniperus monosperma). scrub-oak (Quercus gambelii), serviceberry (Amelanchier utahensis), and cliffrose (Cowania mexicana). Plants found to be particularly intolerant to uranium deposits were sagebrush (Axtemisia begelovii) and hop-sage (Grayia brandegei). Correlations of Cannon's results with the present study are not clear because each is concerned with different forms of uranilim, different geographic locations, and different lengths of exposure to uranium.

On test lines at all the sites, plants with the highest canopy coverage, freguency, and/or density values included grasses such as bottlebrush squirreltail (sitanion hystrix), sagebrush (Artemisia dracunculus). Russian thistle (Salsola kali), and Belvedere sumner-cypress (Kochia scoparla). Grasses and two species of sagebrush (Artemisia dracunculus and $A$. cana) showed the highest canopy coverage, frequency, and/or density values on control lines at all sites. Russian thistle, Belvedere sumer-cypress, and bottlebrush squirreltail are common in disturbed areas such 35 roadsides. Il
Apparently, the most significant factors affecting plant distribution and the results of this study are disturbances, such as burning resulting from weapons tests, and the construction of the mounds at E-F site, rather than uranium concentrations in these areas. The control areas were not adequate for determining how uranium affects plants. This was particularly noticeable at E-. Site, where the tust lines were on a man-made hill and the control lines were in undisturbed areas. To provide proper comparisons between test and control areas, control sites should be located in areas more similar to test areas, with the same amount of disturbance and same degree and direction of slope. Such siting would reduce, or possibly eliminate, the effects of factors other than uranium concentrations on plant distributions.

Plant community analyses were continued during June 1975 to determine vegetative changes as a function of seaso. All plots permanently marked in November 1971, except Minie Site, were reread using the techniques and analyses previously described. Results are shown in Tables $x$ and $X I$. Test lines at E-F Site yielded six species of plants, compared tc only four found the previous fall. K. Scoparia, s. kali. and s. hystriy were again found on all three test lines, along with sisymbriun altissimum. Coverage by the three dominant species wais consiterably reduced from November $197 \%$, indicating that these species had not $y$ eached maturity, as was verified by obscrvation. S. kali (87.58) and s. hystrix (858) were most frequent on Test Lines 1 and 2, respectively: $\underline{k}$. scoparia was most frequent on Test Line 3 . $\underline{s}$. kali and $\underline{s}$. hygtrix had increased on Test Line 1 and 3 , and decreased on Line 2, compared to November values. $K$. scoparia occurred less often on all three lines, although these decreases are probably not significant. Density of the three dominant plant species was not recorded in June. 
TABLE $X$

E-F Site vegetation analyses, JUNE IS 5

Plant Taxan

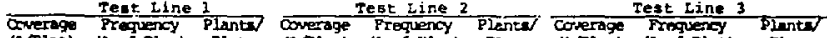

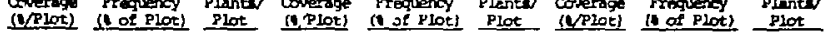

Chenoporisaced

Koctia copparlan-Belvedere Summer-cypres: Salsola kali-Fussinnthistle

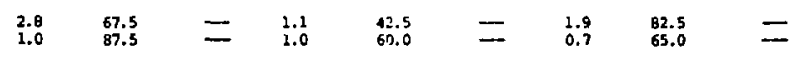

Gindelia spe. Gurved

Coxiferae

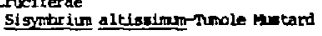

Craminae

(1)

Sytanton hystrix-Botelebrush squirreltull

$\begin{array}{llll}0.5 & 5.0 & 0.1\end{array}$

Aracardiacede

Nhacardiaceale

$\begin{array}{lllllllll}0.6 & 27.5 & 0.5 & 0.2 & 12.5 & 0.1 & 0.3 & 15.0 & 0.1\end{array}$

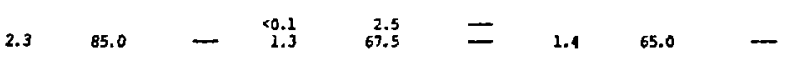

Boraginacese

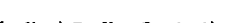

0.1

$2.5<0.1$

0.1

ontrol thes

Compositae

cand-Silver Sagebrush 0.2

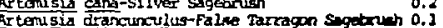

Artenisia fricica-fringed sagebrush

Crósopsig villose-Hairy Goldanter

Figerom divergens-spreading Flaubar

F, rnenoxys tichardsoniti-Pinqu

o. B

7.

0.0

0.5

$.1 \quad 5.0 \quad--$

D.1 2.5

iragoxopon dubitis-Salsi fy

$\begin{array}{lrrr}0.1 & 0.1 & 7.5 & 0.1 \\ & 0.1 & 5.0 & 0.1 \\ & 40.1 & 2.5 & <0.1\end{array}$

$\begin{array}{lll}0.3 & 30.9 & 0.8\end{array}$

ragacese

Quercus anbelii-canbel oak

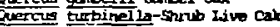

Craminae

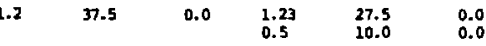

Ceransacese

Ceranium gop. Ceranilu

Lequnumosae

hainus argenteng-5ilvery upine

tiliotur offielralio-suectelover

Linucose

Linum AgP.-Yellon Plax

Dlamonicaene

Scarlet qilde

Dotyconercenes

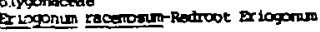

$2.2 \quad 0.0 \quad-\quad 3.5$

(a)

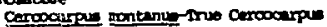

$3.595 .0 \quad-$

ceroptyinateces

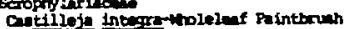

$\begin{array}{lcc}<0.1 & 2.5 & <0.2 \\ <0.1 & 2.5 & <0.2\end{array}$

$<0.1$

2.5

$<0.1$

$\begin{array}{lll}<0.1 & 2.5 & 0.1 \\ 0.4 & 2.5 & 0.5 \\ 0.2 & 17.5 & 0.4 \\ 0.3 & 20.0 & 0.1\end{array}$

$\begin{array}{lll}0.2 & 12.5 & 0.2 \\ 0.1 & 5.0 & 0.1\end{array}$

0.1

$2.5 \quad 0.0$

0.1

2.5

$<0$.

0.1

7.3

0.2 
TABLE XI

LOWER SLOBOVIA AND CONPROL SITE VEGETATION ANALXSES, JUNE 1975

\begin{tabular}{|c|c|c|c|c|c|c|c|c|c|}
\hline \multirow[b]{2}{*}{ Plant Taxan } & \multicolumn{3}{|c|}{ CONTROL } & \multicolumn{3}{|c|}{ LOWER STOBOVIA-IIRE 1} & \multicolumn{3}{|c|}{ LONER SLOBONLA-LDEE 2} \\
\hline & $\begin{array}{l}\text { Coverage } \\
\text { (i/plot) }\end{array}$ & \multirow[t]{2}{*}{$\begin{array}{c}\text { Frequency } \\
\text { (8 of plot) }\end{array}$} & \multirow[t]{2}{*}{$\begin{array}{l}\text { Plantg/ } \\
\text { Plot }\end{array}$} & \multirow[t]{2}{*}{$\begin{array}{l}\text { Coverage } \\
\text { (i/Plot) }\end{array}$} & \multirow[t]{2}{*}{$\begin{array}{l}\text { Frequency } \\
\text { (8 of Plots) }\end{array}$} & \multirow[t]{2}{*}{$\begin{array}{l}\text { Plants/ } \\
\text { Plot }\end{array}$} & \multirow[t]{2}{*}{$\begin{array}{l}\text { Coverage } \\
\text { (8/Plot) }\end{array}$} & \multirow[t]{2}{*}{$\begin{array}{l}\text { Frequency } \\
\text { (1 of Plot) }\end{array}$} & \multirow[t]{2}{*}{$\begin{array}{l}\text { Plants/ } \\
\text { Plot }\end{array}$} \\
\hline Kracardiaceae & & & & & & & & & \\
\hline Phus trilobata-Skunkbush Sumac & & & & 0.2 & 5.0 & 0.0 & 0.4 & 12.5 & 0.0 \\
\hline \multicolumn{10}{|l|}{ Exaglisacese } \\
\hline Gyptantha fendleriffendler oyptantha & 0.1 & 5.0 & 0.1 & 0.3 & 22.5 & 0.5 & 0.1 & 5.0 & 0.1 \\
\hline \multicolumn{10}{|l|}{ Oxpositse } \\
\hline rrtenisia dracunculis-false taragon Sagebrwah & b 1.1 & 60.0 & 1.4 & 0.4 & 15.0 & 0.4 & 1.5 & 60.0 & 1.5 \\
\hline Axtenisia frigida-Fringed Sagebruth & 0.4 & 30.0 & 0.6 & 0.1 & 2.5 & 0.1 & 0.3 & 20.0 & 1.1 \\
\hline Bahia dissecta-Rogleaf Bahio & 0.3 & 2.5 & 0.3 & & & & & & \\
\hline Fellugia paroiala-kpache-plue & & & & 0.5 & 2.5 & 0.0 & & & \\
\hline 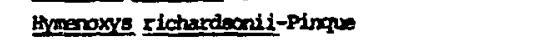 & 0.3 & 15.0 & 0.3 & 20.1 & 2.5 & $<0.1$ & & & \\
\hline Tragopocan dibiu-salaify & 0.3 & 2.5 & 0.0 & $<0.1$ & 2.5 & 0.0 & $<0.1$ & 2.5 & $<0.1$ \\
\hline \multicolumn{10}{|l|}{ cruciferae } \\
\hline 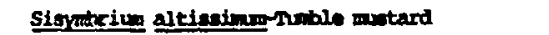 & & & & 0.3 & 20.0 & 0.3 & 0.1 & 10.0 & 0.1 \\
\hline Craminas & 2.8 & $9<.5$ & - & 2.9 & 97.5 & - & 2.4 & 85.0 & - \\
\hline \multicolumn{10}{|l|}{ Imguninosase } \\
\hline Lepinis argentarg-Silvery Iapise & 0.5 & 5.0 & $<0.1$ & & & & & & \\
\hline yicia pp.-vetch & & & & & & & 0.3 & 2.5 & 0.0 \\
\hline \multicolumn{10}{|l|}{ Pulemoniacease } \\
\hline Gilia aggregata-Skyrocket Gilia & & & & & & & 0.3 & 2.5 & 0.3 \\
\hline \multicolumn{10}{|l|}{ serophiviariacese } \\
\hline Qutilleis interetholeleaf Pairthrush & 0.2 & 15.0 & 0.2 & & & & & & \\
\hline
\end{tabular}


An increase of six plant species was recorded on E-F control lines. Again, only S. hystrix was common to both test and control lines. Members of the grass family. Graminae, showed the highest coverage and frequency values on control lines. Grass coverage on the control lines was drastically reduced from November values; frequency values showed no major difference.

other than the grasses, three nembers of the family Compositae which had been found on all three control lines in November were also found on all lines in June. These were Artemisia cana, A. dracunculus, and Chrysopsis villosa. These species also showed generally reduced coverage; but frequency and density were about the same as in November.

Nine species of plants were found on each of the three lines at LS and Control Sites, which was a one-species decrease on each of the two lines at Lower Slobovia. Three new species of plarits not encountered in November were identified on the control site plots in June Two and four new species were also identified on Lines 1 ard 2, respectively, at Lower Slobovia. Four species, Cryptantha fendleri, Artemisia dracunculus, A. frigida, and Tragopogon dubins, were found on all three lines in June. The grasses gave highest coverage and frequency on all three lines, and were too numerous for density determinations. As was true at E-F Site, coverage by grasses and most other plant species was much reduced in June, but frequency was generaily about the same. Five species, Rhus trilobata, Fallugia paradoxa, Sisymbrium altisimum, Vicia spp.. and Gilia aggregata, were identifled on one or both lines at Lower slobovia, but not at control site. Three species, Bahia dissecta, Lupinus argenteus, and sostilleja integra were found only at control site.

Other than the grasses which were again all analyzed as a group. A. dracunculus was the forb that had the highest coverage, frequency, and density on all lines, except for coverage on Line 1 .
Plar: data gathered in November must be more carefully studied in conjunction with present and future data before definitive responses to elevated uranium concentrations can be identified. Present results, however, indicate dominant species at each site which can be studied for uranium concentrating processes on a species level and seasonal basis. At $E-F$ Site, s. hystrix is the dominant species in the spring and early sumer, whereas $\underline{\text { K}}$. scoparia and $\underline{\mathbf{S}}$. kali do not mature until late sumer. At the other sites, $A$. dracunculus, the dominant forb, matures after the summer rains start in July or August. Bromus tectorum is the important spring and early summer grass, which gives way to Bouteloua eripoda (black grama) in late summer and Eall.

B. Small Mammal Populations Associated with the Plant Communities

This initial small mammal study was to determine species composition and diversity, densities, minimal biomass, and uranium concentrations in this component of the ecosystem. Modified North American Census of Small Mamuls (NACSM) trapping lines ${ }^{12}$ (Figs. 3 and 4) in the four study areas were permanently marked in November 1974. Two parallel trap lines $33 \mathrm{~m}$ apart were established at each site. Each line was $160 \mathrm{~m}$ long and consigted of 17 stations at $10-m$ intervals. Three snap traps baited with peanut butter were placed within 1 m of each station in positions most likely to catch small mammals. The trap lines were operated for three consecutive nights.

In June 1975, only one line at each site was operated. Live-trapping was used so that data on movement patterns could be accumulated for this and future trapping sessions. The one trap line at each site was extended from 17 stations to the standard 20 stations/line.

Data recorded on all animals at time of capture included capture location. species identification, sex, age, class, 
reproductive condition, weight, and presence of ectoparasites. The snap-irapped animals were then packaged individually and frozer pending dissection. Measurements of each specimen at dissection included lengths of total body, tail, ear, and hind foot.

The LASL study sites were trapped during November and December 1974 (late fall trapping session) and June 1975 (late spring trapping session). A total of 1224 trap-nights at fowr sites during the fall yielded two species and 124 animals captured at all sites by snap-trapping. The spring live-trapping session at chree sites yielded 126 individuals in 203 total captures of two species during $64 C$ trap-nights.

Both the deer mouse (Peromyscus maniculatus) and the western harvest mouse (Reithrodontomys megalotis) wese trapped at all sites (Table XII). Nine pocket gophers (Thomonys bottae) were captured in dead-traps in June 1975. Peromyscus comprised 70.28 of captures in the fall and 87.78 in the spring.

Trap line positions were determined by anticipated fallout pathways of particulate material from the fixing sites. Therefore, the distance between parallel trap lines was less than that used for standard NACSM estimates of home ranges and populations.

The size of the area sampled for rodent populations (Table XIII) was determined using Brandt's procedure. ${ }^{13}$ His procedure uses home ranges, or average distance between successive points of capture. Initial home range values were also obtained from Brandt by assuming that the differences in different habitats were not significant for these calculations. The values, $52.4 \mathrm{~m}$ for Peromyscus and $32.9 \mathrm{~m}$ for Reithrodontomys, were averages for both sexes during five trapping periods on a grid. The 33-m distance between the parallel trap lines was treated as an overlapping rome range area for both species. Estimated Peromyscus and Reithrodontomys densities, expressed as number per hectare, are presented in Table XIII. Data on Thomomys are incomplete. In June, there were significant density differences among

TABLE XII

SMALL MAMMAL TRAPPING AT IASL URANIUM STUDY SITES IN NOVEMBER 1974 AND JUNE 1975

\begin{tabular}{|c|c|c|c|c|c|}
\hline $\begin{array}{l}\text { Site/ } \\
\text { Date }\end{array}$ & $\begin{array}{r}\text { Total } \\
\text { species } \\
\text { Captured } \\
\end{array}$ & $\begin{array}{l}\text { Total } \\
\text { Individun Is } \\
\text { Captured }\end{array}$ & $\frac{\frac{\text { Peromyscus }}{\text { maniculatus }}}{\text { M:F }}$ & $\frac{\frac{\text { Rei throdontomys }}{\text { megalotig }}}{\mathrm{M:F}}$ & $\frac{\frac{\text { Thamomys }}{\text { bottae }}}{\text { Mi: F }}$ \\
\hline$E-E$ & 3 & 64 & & & \\
\hline $\begin{array}{l}\text { Nov } 74 \\
\text { Jun } 75\end{array}$ & & & $\begin{array}{l}15: 6 \\
20: 19\end{array}$ & $0: 1$ & $2: 1$ \\
\hline Minie & 2 & 56 & & & \\
\hline $\begin{array}{l}\text { Nov } 74 \\
\text { Sun } 75\end{array}$ & & & $20: 17$ & $13: 6$ & 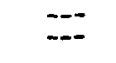 \\
\hline Iower slobovia & 3 & 77 & & & \\
\hline $\begin{array}{l}\text { Nov } 71 \\
\text { Jun } 75\end{array}$ & & & $\begin{array}{l}11: 7 \\
18: 18\end{array}$ & $\begin{array}{l}6: 6 \\
3: 2\end{array}$ & $\overline{1: 5}$ \\
\hline Control & 2 & 62 & & & \\
\hline $\begin{array}{l}\text { Nov } 74 \\
\text { Jun } 75\end{array}$ & & & $\begin{array}{c}5: 6 \\
24: 18\end{array}$ & $\begin{array}{l}3: 2 \\
4: 0\end{array}$ & $\ddot{--}$ \\
\hline
\end{tabular}

\footnotetext{
sex ration expressed as male: female.
} 
TABLE XIII

ESTIMATED SMALL MAMMAL DENSITIES AND MINIMAL BIOMASEES

AT LASL URANIUA STUDY SITES

\begin{tabular}{|c|c|c|c|c|c|c|c|}
\hline \multirow[b]{2}{*}{ Site } & \multirow[b]{2}{*}{ Genu: } & \multicolumn{2}{|c|}{$\begin{array}{l}\text { Area sampled } \\
\text { ger Site thectares) }\end{array}$} & \multicolumn{2}{|c|}{$\begin{array}{c}\text { Denuity } \\
\text { (number/hoctare) }\end{array}$} & \multicolumn{2}{|c|}{ 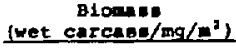 } \\
\hline & & Hoy 74 & Jun 75 & Hov 74 & Jun 75 & Hoy 74 & Jun 75 \\
\hline \multirow[t]{2}{*}{$z-F$} & Peromyscus & 3.67 & 2.83 & 5.7 & 13.8 & 10.3 & 23.3 \\
\hline & Re1 throdontomya & 2.35 & 1.60 & 0.4 & $m$ & $m$ & $-\infty$ \\
\hline \multirow[t]{2}{*}{ Minle } & Peromyscus & 3.67 & & 10.1 & $-m$ & 17.6 & $-\infty$ \\
\hline & Re1throdontorye & 2.35 & & B.I & $\cdots$ & B. 0 & $--\infty$ \\
\hline Lower & Peromyscus & 3.67 & 2.83 & 4.9 & 12.7 & 7.8 & 17.6 \\
\hline Slobuvia & Reithrodontopye & 2.35 & 1.60 & 5.1 & 3.1 & 5.0 & 3.4 \\
\hline \multirow[t]{2}{*}{ Control } & Peromyacus & 3.67 & 2.83 & 3.0 & 14.8 & 5.3 & 20.1 \\
\hline & Asi throdontomy & 2.35 & 1.60 & 2.1 & 2.5 & 2.0 & 2.8 \\
\hline
\end{tabular}

TABIE XIV

WEIGHTS OF ADULT SMLL MAMALS CAFTURED AT LASL URANIUM STUDY SITES (Values are expressed as mean 1 I btd dev for that number ( $n$ ) of animalk.)

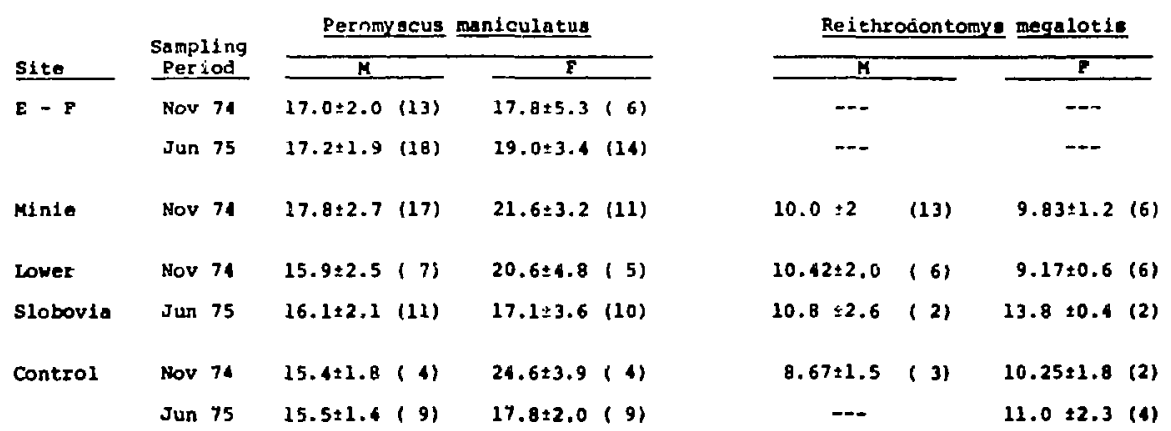

species as measured by student's $t$ test ( $t$ value $=1.0 .6,4$ degrees of freedom) at the 958 confidence level; however, there was no such significant difference in the November 1974 trapping results. Total Peromyscus captures per site were significantly greater than Reithrodontomys captures in both the fall trapping session ( $t=1.84,6 \mathrm{~d} . f ., P \leq 0.10)$ and the spring session ( $P \leq 0.01, t=15.6,4$ d.f.). Mean adult weights by species are listed in Table XIV. Peromyscus males in the DU study sites seemed generally heavier than those at Control site. A one-way analysis of variance of initial fall trapping results indicated that males from $E-F$ and Minie sites were significantly
$(P \leq 0.10)$ heavier than those from control Site $(E-F, F$ value $=3.4 ; 1$ and 14 d.f.; Minie, $F=3.0 ; 1$ and 19 d.f.). Males captured in the spring at E-F Site were again significantly $(P \leq 0.05)$ heavier than control site males $(F=5.7 ; 1$ and 25 d.f.). For Peromyscus females, this trend was reversed; females from control site generally we $31,:$ more than those from $E-F$ and $L S$ $.1 \ldots 3$. 1though the differences were not - $\cdots,+\ldots$ int at the 908 confidence interval. Hignes nean female weights and the larger standard deviations were attributable to pregnant females in the autumn population. Mean adult Reithrodontomys weights showed the same trends, although the differences were not significant $(P \leq 0.10)$ in the fall 
samples. Males were generally heavier at the uranium sites; females, at control site. Too few Reithrodontomys were trapped in the spring for meaningful comparisons.

Peromyscus male:female ratios greater than 1 were recorded at all but one site (Table XII) during each trapping session. This finding was consistent with Peromyscus data in the literature. 14 Reithrodontomys sex ratios also seemed to favor males, as anticipated. 15 Explanations offered include real differences, sex differences in above-ground activity, and larger male home range, which results in greater trap exposure.

Valley pocket gophers, Thomomys bottae, were captured at E-F and Lower Slobovia Sites. Pocket gopher activity was noted at all sites, and they could conceivably make up a significant portion of the small mammal biomass. Their continuous burrowing and pushing of scil to the surface promotes vertical cyciling and mixing of soil constituents and probably redistrikutes uranium. Future small mammal studie. will emphasize $T$. bottae.

c. Small Macrofaunit of Soil and Litter at LASL Study sites

Litcer- and soil-inhabiting invertebrates were extracted by use of the Tullgren funnel techniçue ${ }^{16}$ from $1-\mathrm{dm}^{3}$ soil cores removed from areas of uranium contamination and nearby control areas at E-F and LS sites. As far as possible, soil, vegetation, and topography of the experimental and control areas were similar at each site. The distributions of the organisms were characterized and compared to ascertain possible differences that might be due to ecological changes caused by presence of uranium.

The organisms obtained were $0.2-2.0 \mathrm{~mm}$ long. Microfauna $<0.2 \mathrm{~mm} 1 \mathrm{cng}$, particularly microscopic forms, were not sampled, and few of the larger (>2.0 mm) animals, which would be better sampled by pitfall traps or other methods, were not studied.
1. Populations and Characteristics. At least 70 species of invertebrates were collected from the iimited number of soil cores extracted; we anticipate that $>100$ species will be identified as studies progress.

About 10 common species dominated the specimens. Relative densities of the major groups, expressed as per cent of all specimens extracted, were as follows:

Acarina (several species of mites) 70 Collembola ( 3 species of springtails)

Thysanoptera (1 specie of $t$ rips) 16 Hemiptera and Homoptera (many species)

Culeoptera (several species of beetles)

Diptera (fiies, mainly one species) 3 Hymenoptera (mainly one species of ant)

Miscellaneous (10 groups, 20-30 families)

Table XV is a complete phylogenetic listing of the groups and an estimate of the numbers of species in each. The variety of animals did not differ greatly frnm that reported in other North American studies, although there seened to be fewer Psocoptera (book lice), Chelonethida TABLE XV

MCROFAUN RECOVERED FRCM IITIER AND SOTE SANPLS AT LAST.

\begin{tabular}{|c|c|c|c|c|}
\hline Phylu & Class: & Order & Family & $\begin{array}{c}\text { No. of } \\
\text { Species }\end{array}$ \\
\hline 1. Annelifia & Oligorheta & & & 1 \\
\hline 2. Nematoda & & & & 1 \\
\hline 3. Arthropoda & Mrachnida & Acarine & & $25-50$ \\
\hline 4. & Arachnida & Mraneida & & 3 \\
\hline s. & Ch1 lopoda & & Lithoblidae & Lithodium? \\
\hline s. & Bymphy 1. & & & 1 \\
\hline 7. & Inaecen & Thyosanura & & 1 \\
\hline •. & Diplure & Inpyg1dne & & 1 \\
\hline 9. & & Cotleabola & Sminehuridae & 1 \\
\hline 10. & & & Podurtdae & 1 \\
\hline 21. & & & Entomobryildae & 1 \\
\hline 12. & & Psocoptere & & 1 \\
\hline 13. & & Thyoanoptera & & $1-3$ \\
\hline if. & & Beniptere & & $1=3$ \\
\hline 25. & & Bomopter: & Clcadellidas & $1-2$ \\
\hline 16. & & Homopter. & & $2-1$ \\
\hline \multirow[t]{7}{*}{17.} & & Coleoptern & Eleterlane & 1 \\
\hline & & & stuphylinidae & 2 \\
\hline & & & Carabidee & 1 \\
\hline & & & Gearabse1doe & 1 \\
\hline & & & Phynchophoren & 1 \\
\hline & & & Anthlcidae & Notokus \\
\hline & & & Mlecellaneoun & $1-3$ \\
\hline 10. & Lapidoptera & & & $2-5$ \\
\hline \multirow[t]{5}{*}{19.} & Dipters & & Coeldeogyildae & (3) \\
\hline & & & Phor Idae & \\
\hline & & & Tachinidae & $10-15$ \\
\hline & & & Mycetophilldae & \\
\hline & & & Muecidae & \\
\hline 20. & & Hymanoptira & Pormiclatae & 2 \\
\hline 22. & & & Tiphlidere & 2 \\
\hline
\end{tabular}


(pseudoscorpions), and Araneida (spiders) than are commonly found in chaparral, desert, piñon-juniper, and coniferous forests of the western United States. This apparently reduced number is not presently considered significant.

A total of 3218 specimens was isolated from 97 valid litter and soil samples. Nearly 2300 of these were mites; with a relative density (RD = per cent of total animals) of 718 and a frequency $(F=$ per cent of occurrence in samples) of 918 . The mites included 25-50 species, of which 10 were common. More than 500 springtails (RD $=168, F=688$ ) of 5 species (of which 2 were very commor) were collected. The mean number of specimens per sample was 33 . About half the samples contained < 15 specimens, 5 contained 112-505 specimens, and the rest contained 15-30. Specimens were fewest in samples collected during dry periods, and the greatest numbers were found in cores taken during a 4-day period when rainfall tataled $0.88 \mathrm{~cm}$. Most litter animals are sensitive to rainfall and soil moisture, and the greater numbers of animals found in the last samples were probably due to increased soil moisture.

2. Abundance of Various Species and Groups in Test and Control Areas. The frequency of an organism, or the per cent of samples in which it occurred, was considered a measure of its abundance because the various animals encountered in this phase of the study were of the same general size. Such frequencies are presented in Table XVI, along with a second value, relative frequency, for each group of animals to facilitate comparison with all other groups. In general, the data indicate that one is equally likely to find any group at the test areas and the control areas. Diptera were more abundant at the test areas, perhaps because of the more open habitat resulting from fires started during past tests.

The invertebrate studies were to determine whether animal populations in close contact with uranium would demonstrate
TARE XVI

FREQUENEIES OF MUJOR MACROFNON GROUPS IM 97 CORI SMXLES (heletive frequencles, RP, are an expreasion of the pex

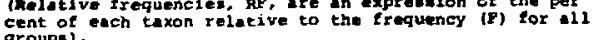

\begin{tabular}{|c|c|c|c|c|c|}
\hline \multirow[b]{2}{*}{ Texon } & \multirow[b]{2}{*}{ Index } & \multicolumn{2}{|c|}{ Teat Mreas } & \multicolumn{2}{|c|}{ Control Arets } \\
\hline & & $2-F$ & $\begin{array}{c}\text { Lowar } \\
\text { slobovla }\end{array}$ & E-P & $\begin{array}{c}\text { Control } \\
\text { Slet } \\
\end{array}$ \\
\hline $\begin{array}{l}\text { Acerina } \\
\text { (al ted and elcks) }\end{array}$ & $\underset{R P}{P}$ & 75 & $\begin{array}{r}100 \\
36\end{array}$ & 24 & $\begin{array}{l}95 \\
36\end{array}$ \\
\hline $\begin{array}{l}\text { Collembola } \\
\text { (apringteile) }\end{array}$ & $\underset{R P}{\mathbf{F}}$ & $\begin{array}{l}29 \\
12\end{array}$ & 23 & $\begin{array}{l}96 \\
25\end{array}$ & $\begin{array}{l}61 \\
19\end{array}$ \\
\hline $\begin{array}{l}\text { Thyeanoptera } \\
\text { (thrips) }\end{array}$ & $\stackrel{p}{R}$ & 17 & 17 & 2 & $\begin{array}{l}30 \\
10\end{array}$ \\
\hline $\begin{array}{l}\text { Bonopters and } \\
\text { Bemiptera } \\
\text { (buge) }\end{array}$ & $\underset{p P}{F}$ & $\begin{array}{r}33 \\
7\end{array}$ & 17 & 31 & $\begin{array}{l}7 \\
5\end{array}$ \\
\hline $\begin{array}{l}\text { Coleopters } \\
\text { (beetles) }\end{array}$ & $\underset{R}{F}$ & $\begin{array}{l}25 \\
10\end{array}$ & 21 & 12 & $\begin{array}{l}30 \\
10\end{array}$ \\
\hline $\begin{array}{l}\text { Diptera } \\
\text { (Eiles) }\end{array}$ & $\underset{\mathbf{R P}}{\mathbf{P}}$ & $\begin{array}{l}54 \\
22\end{array}$ & $\begin{array}{l}88 \\
23\end{array}$ & $\begin{array}{l}54 \\
14\end{array}$ & $\begin{array}{l}52 \\
16\end{array}$ \\
\hline $\begin{array}{l}\text { Hymenoptera } \\
\text { (onts) }\end{array}$ & $\stackrel{P}{P}$ & $\begin{array}{r}12 \\
5\end{array}$ & $\begin{array}{r}33 \\
9\end{array}$ & 42 & $\begin{array}{r}17 \\
5\end{array}$ \\
\hline Mi scel laneous & $\mathbf{F}$ & $-\overline{6}$ & $-\overline{7}$ & $\overline{10}$ & $-\overline{5}$ \\
\hline TOThLs & $\mathbf{R P}$ & 100 & 130 & 100 & 100 \\
\hline
\end{tabular}

measureable differences within each exposure level. The number of samples is inadequate to show whether such differences exist. Population densities of all groups except Acarina were less in the controi areas than in the test areas.

The two control areas had generally similar invertebrate populations, although Collembola species were much fewer at Control site. This reduction may be due to temperature and moisture factors that will require selection of a different sampling locatior.

Invertebrate populations in the intermediate uranium iest site, Lower Slobovia, contained more individuals and taxonomic groups than those in the high uranium test site, E-F site. However, the variety of species in the two sites was not significantly different. Throughout the study, there was difficulty in interpreting the data because of inconsistent trends due to an insufficient number of samples and interference of several environmental parameters other than a uranium difference among sites.

There was no evidence that observed differences in invertebrate populations were caused by toxic responses to uranium. 
Similar results would be expected because of the physical disturbances of firing mound construction, fires, or other common human activities.

\section{SUMMARY AND CONCLUSIONS}

The ecological consequences of releasing uranium to terrestrial ecosystems during development and testing of depleted uranium munitions were investigated. Soil samples from EAFB, Florida, were collected $60,120,180$, and 240 ft $(18,37,55$, and $73 \mathrm{~m})$ from armor plate target butts struck by depleted uranium penetrators. These were separate samples of the upper and lower $5 \mathrm{~cm}$ at each location. The highest uranium concentrations were in the top $5 \mathrm{~cm}$. Samples from beyond about $20 \mathrm{~m}$ showed near-background levels of natural uranium, or about $2.3 \pm 1.0 \mu \mathrm{g} / \mathrm{g}$ (ppm). Samples taken at target bases contained an average of 800 ppm of uranium in the upper $5 \mathrm{~cm}$; generally 30 times as much as in the lower $5 \mathrm{~cm}$, indicating modest vertical moverent of depleted uranium into the soil. Saniles taken at $18 \mathrm{~m}$ contained averages of 20 and 2 ppn in the upper and lower $5 \mathrm{~cm}$, respectively.

Two explosives-testing areas at IASL were selected for study on the basis of their use history: E-F site, with averages of 2400 ppm of uranium (natural and depleted) in the upper $5 \mathrm{~cm}$ of soil and $1600 \mathrm{ppm}$ at 5-10 cm; and two subplots at Lower slobovia in which soil uranium concentrations were about 2.5 and 0.68 of the $E-F$ site values. Important concentration differences with depth and distance from detonation points were ascribed to the different explosive test designs peculiar to each area.

Vegetation samples at E-F site contained about $320 \mathrm{ppm}$ in November 1974 and about 125 ppm in June 1975. These differences were probably due to (1) variable external deposition over considerable time; (2) different species of plants available at different times; and (3) greater amounts of fresh growth in the June samples. Ratios of plant:soil uranium concentratiuns varied from 0.08 in November to 0.05 in June, within the range reported from other studies of plants in high uranium areas.

small mammals trapped in November contained a maximum of 210 prm of uranium in GI tract contents, $24 \mathrm{ppm}$ in the pelt, and $4 \mathrm{ppm}$ in the remaining carcass. In June, maximum concentrations were 110, 50, and 2 ppm in similar samples and 6 ppm in lungs. These data emphasize the importance of resuspension of respirable particles in the upper few millimeters of soil as a contamination mechanism in several components of the ecosystem.

Vegetation community analyses and initial results of the soll invertebrate studies did not reveal conclusive differences in the effects of the various gradients of uranium in the study and control sites. Soil and litter macrofauna diversities and populations seemed reduced at the high uranium study area compared to the adjacent control area, but more samples are required to determine the significance of the observation. The anamolous character of the E-F firing mound complicated the faunistic studies because it strongly influenced soil moisture, absorbed solar radiation, and aspect responses. The study areas may have to be moved to achieve similarity.

Both EAFB and LASL soil analyses indicated that relatively large fragments as well as fine particulates from uranium explosive tests corrode readily and then migrate into the soil at variable rates. Weathering is apparently faster in the humid environment and porous soil at EAFB than at L.ASL.

\section{ACKNOWLEDGMENTS}

Plant community analyses were by Maureen Romine of New Mexico Highlands University. Donald $C$. Lowrie separated, identified, and summarized soil macrofauna. We heartily appreciate their efforts. 
Environmental Studies Group personnel who deserve recognition include $K$. $V$. Bustick for supervising sample processing; $\mathrm{J}$. Owens for conducting uranium analyses; and D. W. Garaner, J. L. Martinez, G. M. Romero, and E. Trujillo for technical assistance.

L. M. Bagget and $J$. E. Travis of LASL's Dynamic Test:ing Division provided study site use histories ar. tharacterizations. We thank the New Mexico Department of Game and Fish for permission to collect small mammals.

\section{REFERENCES}

1. W. C. Hanson, "Ecological Considerations of Depleted Uranium Munitions," Los Alamos Scientific Laboratory report LA-5559 (1974).

2. W. C. Hanson, "Proposal to Designate Land Areas of the Los Alamos Scientific Laboratory as a National Environmental Research Park," in National Environmental Research Park symposium, D. Parsons, Ed. The Snake River Regional studies Center, College of Idaho, Caldwell, Idaho, 1975.

3. R. Daubenmire, "A Canopy-Coverage Method of Vegetational Analysis," Northwest science 33 (1), 43-64 (1959).

4. H. D. Harrington, Manual of the Plants of Colorado, (Sage Books, Denver, Colorado, 1964).

5. "Check List of Native vegetation in the Southwestern Region," Region 3, Forest Service, U. 5 . Department of Agriculture (1963).

6. F. A. Centann and T. Morrison, Jr., "Improvements in the Fluorometric Determination of Uranium," Raw Materials Development Laboratory, winchester, Massachusetts, Topical Report WIN-63 (1957).
7. P. Galvanek, Jr., and T. Morrison, Ir., "A New Fluorimeter for the Determination of Uranium," Raw Materials Development Laboratory, Winchester. Massachusset.ts, Topical keport ACCO-47 (1954).

8. I. J. Johnson, "Los Alamos Land Areas Environmental Radiation Survey 1972," Los Alamos Scientific Laboratory report LA-5097-MS (November 1972).

9. H. I. Cannon, "The Effect of UraniumVanadium Deposits on the Vegetation of the Colorado Plateau," Am. J. Sci. 250, 735-770 (1952).

10. W. G. Bradley and K. S. Moor, "Ecological Studies of Small Vertebrateg in Pu-Contaminated Study Areas of NTS and TTR," Pp. 151-185. In M. G. White and P. B. Dunaway, Eds., "The Radioecology of Plutonium and other Transuranics in Desert Environments," US ERDA report NVo-153, Las Vegas, Nevada (1975).

11. W. A. Weber, Rocky Mountain Flora, (University of Colorado Press, Boulder, Colorado, 1967).

12. J. :. Calhoun, Ed., "North American Census of Small Mamma1s," National Institutes of Health, Bethesda, Maryland, 1948.

13. D. H. Brandt, "Measures of the Movements and Population Densities of Small Rodents," Univ Calif. Publ. zool. 62, 105-184 (1962).

14. C. R. Terman and J. F. Sassaman, "Sex Ratio in Deer Mouse Population," J. Mamm. 48 (4), 589-597 (1967).

15. G. H. Riching, H. D. Smith, and C. D. Jorgensen, "Growth and Development of the Western Harvest Mouse, Reithrodontomys megalotis," Great Basin Natiralist 34, 105-120 (1974).

16. A. MacFadyen, "Note 3 on Methods for the Extraction of Small Soil Arthropods," J. Animal Ecol. 22, 65-77 (1953). 
APPENDIX A

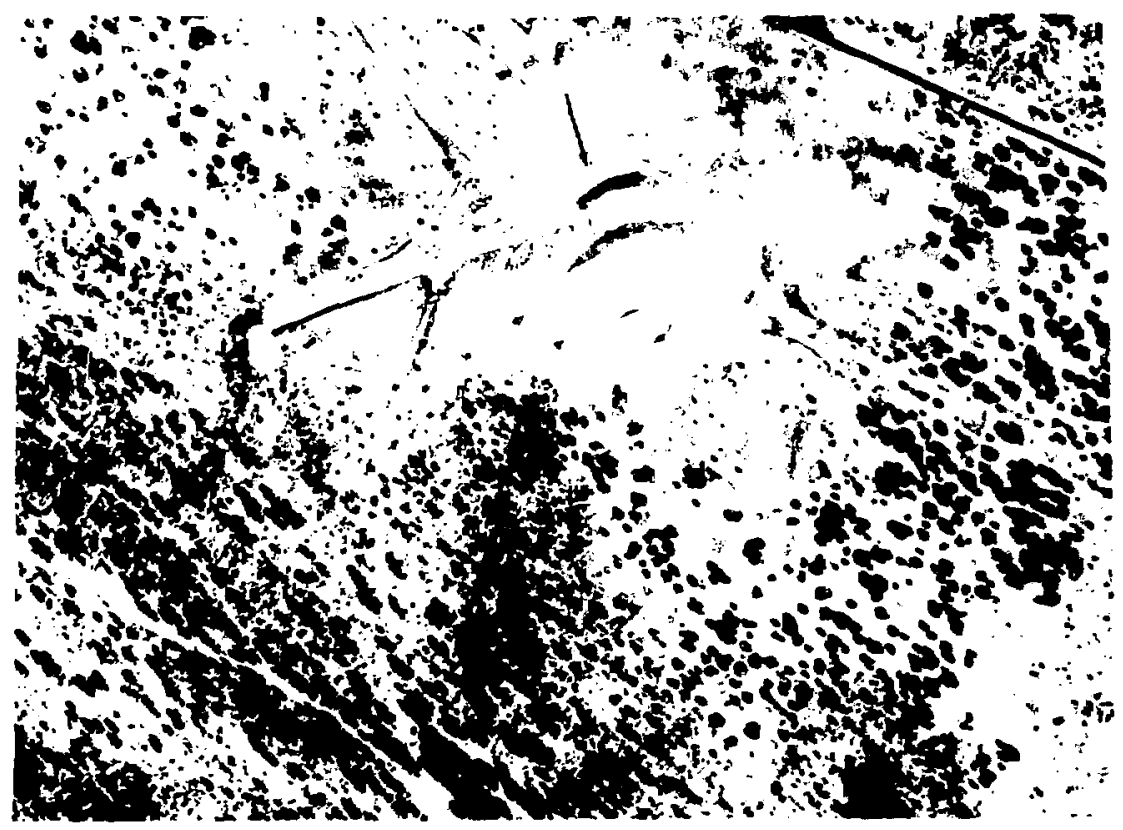

Fig. A-1. Aerial view of E-F site showing the firing mound (arrow). Note lack of vegetative overstory which has been burned and cleared.

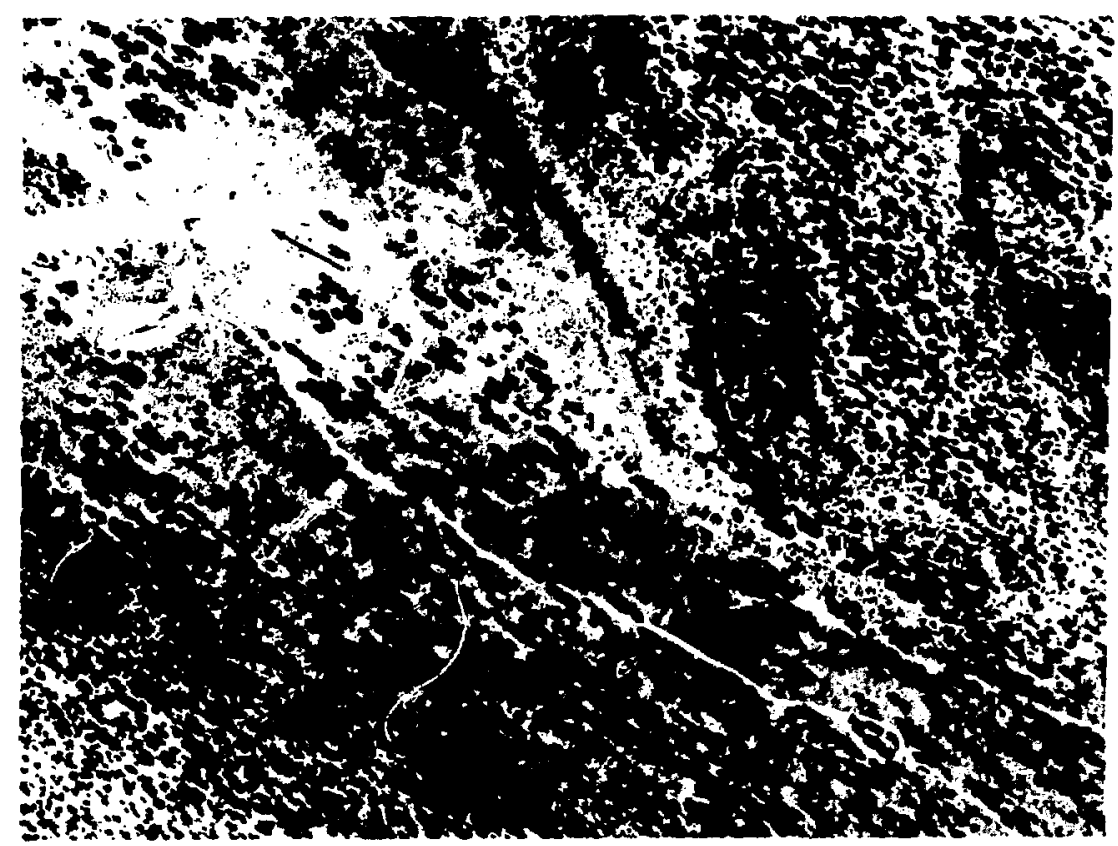

Fig. A-2. Aerlal view of Lower slobovia (ai row) showing elimination of most of the overstory north of the firing mound. Control site is in the lower right-hand corner of the piotograph. 


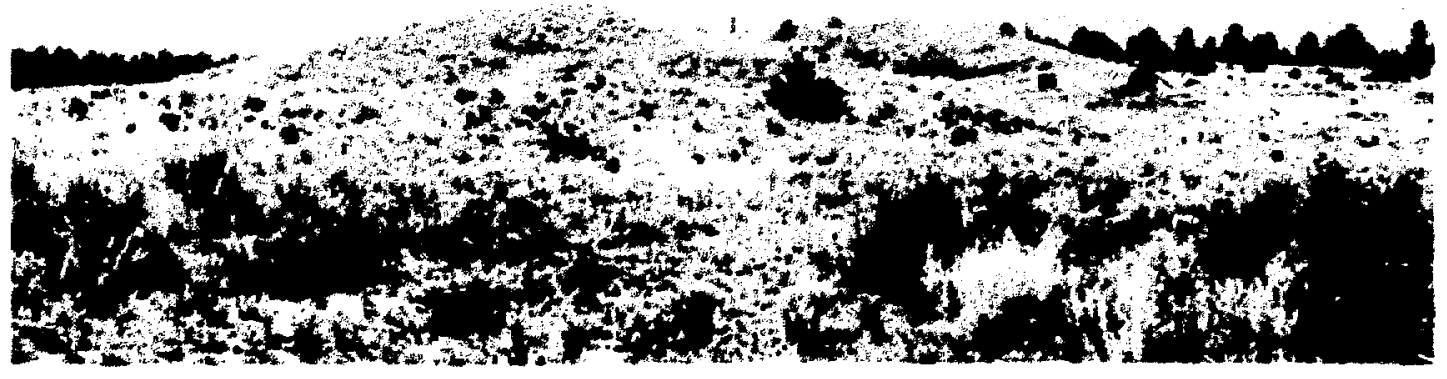

Fig. A-3. E-F Site from the southeast, agein showing lack of overstory vegetation surrounding the site. Weapons tests aze conducted between the two man-made mounds.

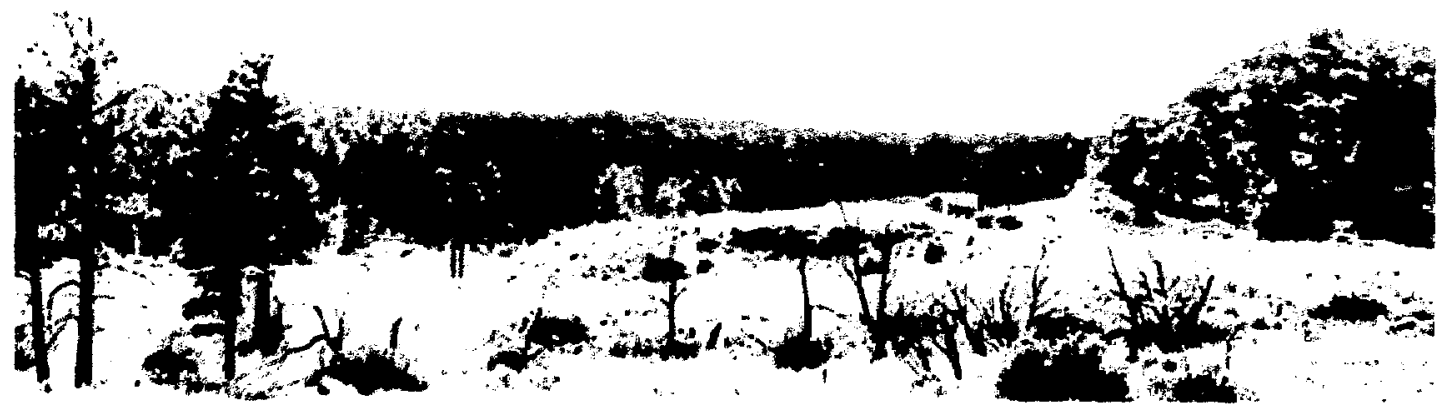

Fig. A-4. Lower slobovia trom the northeast. The firing mound is in the center. Again, most of the overstory vegetation has been burned.

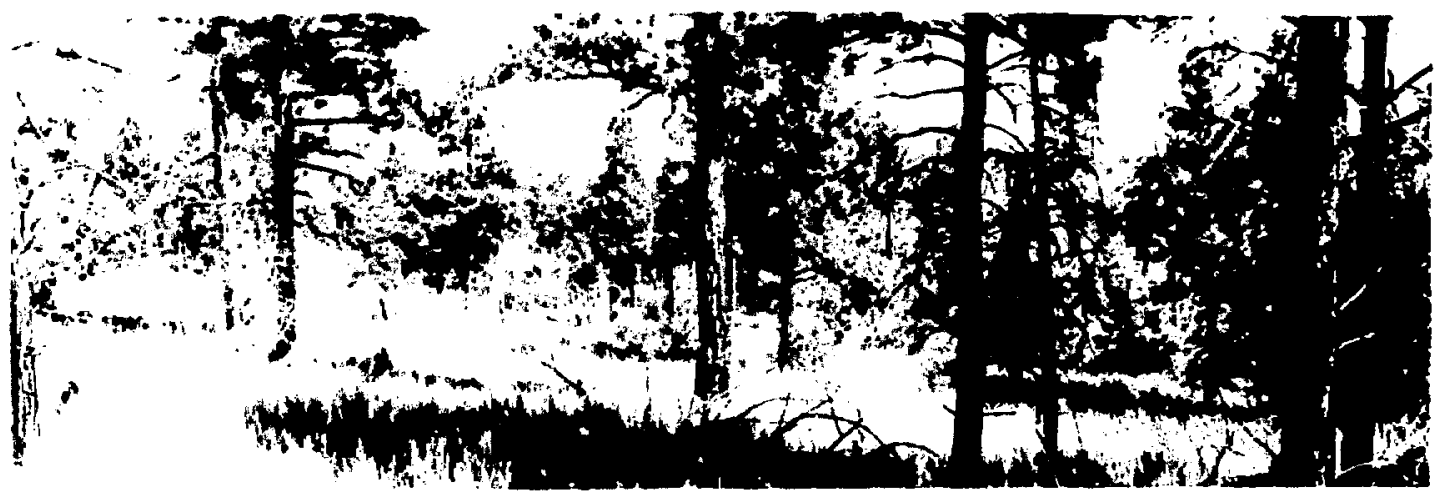

Fig. A-s. Control site from the east. The overstory is Ponderosa pine (Pinus ponderosa), Juniper (Juniperus spp.), and Piñon Pine (Pinus edulis). 
APPENDIX $B$

RESULTS OF URANIUM ANALYSES OF SOIL SAMPLES

TABLE B-I

NATURAL AND DEPLETED URANIUM IN SOIL SAMPLES

(Comparison of IASL and Eberline Analyses)

\begin{tabular}{|c|c|c|c|c|c|}
\hline sample & Designation ${ }^{a}$ & $\begin{array}{l}\text { LASL } \\
\text { NO. }\end{array}$ & $\begin{array}{c}\text { Eberline } \\
\text { No. }\end{array}$ & $\begin{array}{c}\text { LASL } \\
(\mu g \mathrm{~g} / g) \\
\end{array}$ & $\begin{array}{l}\text { Eberline } \\
(\mu \mathrm{g} U / \mathrm{g})\end{array}$ \\
\hline $\begin{array}{l}\text { Eglin } \\
\text { Standard } \\
\text { Eglin }\end{array}$ & $\begin{array}{l}0-0-A \\
S-3 \\
0-0-B \\
1-1-A \\
1-1-B \\
1-3-A \\
1-3-B \\
1-3-B b \\
1-5-A \\
1-5-B \\
1-7-A \\
S-4\end{array}$ & $\begin{array}{r}102 \\
103 \\
98 \\
91 \\
93 \\
85 \\
85 \\
89 \\
99 \\
87\end{array}$ & $\begin{array}{r}1 \\
2 \\
3 \\
4 \\
5 \\
6 \\
7 \\
8 \\
9 \\
10 \\
11 \\
12\end{array}$ & $\begin{array}{c}910 \\
4270 \\
26 \\
20 \\
\text { N.D. } \\
6.7 \\
\text { N.D. } \\
\text { N.D. } \\
2.0 \\
2.0 \\
0.8 \\
3770\end{array}$ & $\begin{array}{r}900 \\
3210 \\
31 \\
9.2 \\
0.5 \\
4.2 \\
0.3 \\
1.7 \\
2.0 \\
1.6 \\
2.9 \\
2850\end{array}$ \\
\hline Stancard & $\begin{array}{l}1-7-B \\
1-9-A \\
1-9-B \\
1-11-A \\
1-11-A b \\
1-11-B \\
1-13-A \\
1-13-B \\
1-15-A \\
1633\end{array}$ & $\begin{array}{l}94 \\
95 \\
97 \\
96 \\
96 \\
88 \\
92 \\
90 \\
84\end{array}$ & $\begin{array}{l}13 \\
14 \\
15 \\
16 \\
17 \\
18 \\
19 \\
20 \\
21 \\
22\end{array}$ & $\begin{array}{c}1.2 \\
11 \\
0.9 \\
94 \\
94 \\
11 \\
18 \\
N . D . \\
10 \\
1615\end{array}$ & $\begin{array}{r}0.6 \\
12.7 \\
1.4 \\
40.5 \\
40.5 \\
7.2 \\
22.5 \\
1.3 \\
2.5 \\
1580\end{array}$ \\
\hline Eglin & $\begin{array}{l}1-15-B \\
2-10-A \\
2-10-B \\
2-12-A^{b} \\
2-12-A b \\
2-12-B \\
2-2-A_{b} \\
2-2-B b \\
2-2-B^{b}\end{array}$ & $\begin{array}{l}86 \\
75 \\
74 \\
72 \\
72 \\
73 \\
78 \\
76 \\
76\end{array}$ & $\begin{array}{l}23 \\
24 \\
25 \\
26 \\
27 \\
28 \\
29 \\
30 \\
31\end{array}$ & $\begin{array}{c}\text { N.D. } \\
5.4 \\
4.1 \\
19 \\
19 \\
1.2 \\
1.8 \\
\text { N.D. } \\
\text { N.D. }\end{array}$ & $\begin{array}{l}1.5 \\
4.3 \\
0.9 \\
1.6 \\
1.7 \\
0.4 \\
2.0 \\
0.3 \\
0.2\end{array}$ \\
\hline Standard & $\begin{array}{l}4-2-A \\
2-4-A \\
4-2-B \\
3-9-A \\
3-9-B \\
3-13-A \\
3-13-B \\
3-1-A \\
3-1-B \\
3-5-A \\
5-3\end{array}$ & $\begin{array}{l}79 \\
80 \\
77 \\
68 \\
67 \\
65 \\
66 \\
71 \\
64 \\
69\end{array}$ & $\begin{array}{l}32 \\
33 \\
34 \\
35 \\
36 \\
37 \\
38 \\
39 \\
40 \\
41 \\
42\end{array}$ & $\begin{array}{c}\text { N.D. } \\
1.4 \\
\text { N.D. } \\
4.3 \\
\text { N.D. } \\
1.0 \\
\text { N.D. } \\
0.8 \\
\text { N.D. } \\
2.0 \\
4270\end{array}$ & $\begin{array}{r}0.6 \\
1.6 \\
0.2 \\
2.6 \\
0.1 \\
0.2 \\
\text { N.D. } \\
0.9 \\
0.6 \\
1.0 \\
2760\end{array}$ \\
\hline $\begin{array}{l}\text { Sand } 1 \\
\text { Standard }\end{array}$ & $\begin{array}{l}3-5-B \\
3-7-A \\
3-7-B \\
4-10-A \\
4-10-B \\
4-12-A \\
4-12-B \\
2-4-B \\
B 1 \text { ank } \\
5-4\end{array}$ & $\begin{array}{l}70 \\
63 \\
62 \\
60 \\
61 \\
58 \\
59 \\
81\end{array}$ & $\begin{array}{l}43 \\
44 \\
45 \\
46 \\
47 \\
48 \\
49 \\
50 \\
51 \\
52\end{array}$ & $\begin{array}{c}1.8 \\
2.9 \\
3.1 \\
0.6 \\
1.2 \\
1.0 \\
1.4 \\
\text { N.D. } \\
\text { N.D. } \\
3770\end{array}$ & $\begin{array}{r}0.8 \\
1.6 \\
1.9 \\
0.7 \\
0.3 \\
0.9 \\
0.3 \\
0.3 \\
0.3 \\
1680\end{array}$ \\
\hline
\end{tabular}


TABLE B-I (Continued)

\begin{tabular}{|c|c|c|c|c|c|}
\hline Sample & Degignation & $\begin{array}{l}\text { LASL } \\
\text { No. }\end{array}$ & $\begin{array}{l}\text { Eberline } \\
\text { No. }\end{array}$ & $\begin{array}{c}\text { LAsL } \\
(\mu g \quad U / g) \\
\end{array}$ & $\begin{array}{l}\text { Eberline } \\
\text { (ug } u / g)\end{array}$ \\
\hline Eglin & $\begin{array}{l}4-4-A \\
4-4-B \\
\text { Control A } \\
\text { Control B } \\
0-0-A \\
0-0-B \\
\text { Ditch 5-3-A } \\
\text { Ditch 5-3-B }\end{array}$ & $\begin{array}{r}56 \\
57 \\
54 \\
55 \\
100 \\
101 \\
82 \\
83\end{array}$ & $\begin{array}{l}53 \\
54 \\
55 \\
56 \\
57 \\
58 \\
59 \\
50\end{array}$ & $\begin{array}{l}1.2 \\
2.3 \\
4.8 \\
3.0 \\
680 \\
40 \\
\text { N.D. } \\
\text { N.D. }\end{array}$ & $\begin{array}{r}0.6 \\
\text { N.E. } \\
0.3 \\
0.3 \\
390 \\
26.5 \\
0.7 \\
0.3\end{array}$ \\
\hline $\begin{array}{l}\text { EF-FP } \\
\text { Standard } \\
\text { LS } \\
\text { EF-FP } \\
\text { EF-F: } \\
\\
\text { Sand } 1\end{array}$ & 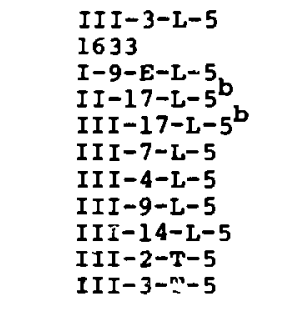 & $\begin{array}{l}52 \\
51 \\
24 \\
24 \\
50 \\
49 \\
46 \\
48 \\
47 \\
44\end{array}$ & $\begin{array}{l}61 \\
62 \\
63 \\
64 \\
65 \\
66 \\
67 \\
68 \\
69 \\
70 \\
71 \\
72\end{array}$ & $\begin{array}{r}1780 \\
1615 \\
24 \\
1590 \\
1590 \\
220 \\
2200 \\
78 \\
1470 \\
5100 \\
2930 \\
\text { N.D. }\end{array}$ & $\begin{array}{c}2.8 \\
1520 \\
17.5 \\
1230 \\
1110 \\
133 \\
1760 \\
44 \\
940 \\
3390 \\
1180 \\
1.0\end{array}$ \\
\hline LS & $\begin{array}{l}I-8-E-T-5^{b} \\
I-8-E-T-5 b \\
I-5-C-T-5 \\
I I-4-S C-L-5\end{array}$ & $\begin{array}{l}21 \\
21 \\
41 \\
42\end{array}$ & $\begin{array}{l}73 \\
74 \\
75 \\
76\end{array}$ & $\begin{array}{r}220 \\
220 \\
139 \\
19\end{array}$ & $\begin{array}{l}32 \\
23 \\
16 \\
1.2\end{array}$ \\
\hline $\begin{array}{l}E F-F P \\
\text { Sand } 1\end{array}$ & $\begin{array}{l}\text { II I-9-T-5 } \\
\text { II I- } 13-L-5 \\
\text { I II }-10-T-5 \\
\text { III- } 11-L-5\end{array}$ & $\begin{array}{r}43 \\
5 \\
38 \\
39\end{array}$ & $\begin{array}{l}77 \\
78 \\
80 \\
81 \\
82\end{array}$ & $\begin{array}{l}386 \\
660 \\
886 \\
158 \\
\text { N.D. }\end{array}$ & $\begin{array}{r}420 \\
620 \\
940 \\
164 \\
0.2\end{array}$ \\
\hline$E F-F P$ & $\begin{array}{l}\text { II I }-17-T-5 \\
\text { III-12-L-5 } \\
\text { I II }-12-I-5^{b} \\
\text { I-SW-T-5 }\end{array}$ & $\begin{array}{l}40 \\
35 \\
35 \\
45\end{array}$ & $\begin{array}{l}83 \\
84 \\
85 \\
86\end{array}$ & $\begin{array}{r}1460 \\
264 \\
264 \\
5.1\end{array}$ & $\begin{array}{r}1230 \\
345 \\
280 \\
3.4\end{array}$ \\
\hline Sand 1 & $\begin{array}{l}\text { III- } 11-T-5 \\
\text { III-13-T-5 } \\
\text { III-10-L-5 } \\
\text { III }-18-T-5 \\
\text { III }-6-L-5\end{array}$ & $\begin{array}{l}34 \\
36 \\
37 \\
10 \\
18\end{array}$ & $\begin{array}{l}87 \\
88 \\
89 \\
90 \\
91 \\
92\end{array}$ & $\begin{array}{r}7550 \\
1810 \\
250 \\
1760 \\
252 \\
\text { N.D. }\end{array}$ & $\begin{array}{l}590 \\
880 \\
295 \\
760 \\
130 \\
0.6\end{array}$ \\
\hline $\begin{array}{l}\text { LS } \\
\text { EF-FP }\end{array}$ & $\begin{array}{l}I-4-W-T-5 \\
\text { II I-16-T-5 } \\
\text { III-6-T-5 } \\
\text { II I-8-L-5 } \\
\text { III-12-T-5 } \\
\text { III-15-L-5 } \\
\text { II-3-SC-T-5 } \\
\text { II-3-SC-T-5b }\end{array}$ & $\begin{array}{r}20 \\
53 \\
12 \\
9 \\
1 \\
29 \\
31 \\
31\end{array}$ & $\begin{array}{r}93 \\
94 \\
95 \\
96 \\
97 \\
98 \\
99 \\
100\end{array}$ & $\begin{array}{r}139 \\
1840 \\
646 \\
75 \\
1240 \\
285 \\
2.7 \\
2.7\end{array}$ & $\begin{array}{r}190 \\
1080 \\
510 \\
130 \\
880 \\
320 \\
2.6 \\
2.0\end{array}$ \\
\hline $\begin{array}{l}a_{A}=\text { upper } \\
b_{\text {Replicate }} \\
\text { AEC Ref. } \\
\text { AEC Ref. } \\
\text { U. S. Bur }\end{array}$ & $\begin{array}{l}\text { c.5 } \mathrm{Am} ; \mathrm{B}=\text { lower } \\
\text { e samples submitted } \\
\text { Sample } \mathrm{S}-3 \quad 0.4188 \\
\text { Sample } \mathrm{S}-40.375 q \\
\text { reau of Standards Fl }\end{array}$ & $\begin{array}{l}0.5 \text { dm. } \\
\text { to Eberline } \\
\text { ysh } 1633\end{array}$ & $11 \mu \mathrm{g} / \mathrm{g}$ & & \\
\hline
\end{tabular}


TABLE B-II

LASL URANIUM ANALYSIS OF EGLIN APB SOILS

\begin{tabular}{|c|c|c|c|c|c|}
\hline $\begin{array}{l}\text { EAFB } \\
\text { Sample } \\
\text { No.a }\end{array}$ & $\begin{array}{l}\text { LASL } \\
\text { Lab } \\
\text { No. }\end{array}$ & $\begin{array}{l}\text { Field } \\
\text { Weight } \\
\text { lin. }\end{array}$ & $\begin{array}{l}\text { Lab } \\
\text { Sample } \\
\text { (grams) }\end{array}$ & \multicolumn{2}{|c|}{$\mu \mathrm{sg} u / g$} \\
\hline $\begin{array}{l}0-0-A \\
0-n-A \\
0-0-B \\
0-0-B\end{array}$ & $\begin{array}{l}102 \\
100 \\
103 \\
101\end{array}$ & $\begin{array}{l}910 \\
684 \\
784 \\
676\end{array}$ & $\begin{array}{l}5.574 \\
0.921 \\
6.264 \\
6.132\end{array}$ & $\begin{array}{r}910 \\
690 \\
26 \\
40\end{array}$ & $\begin{array}{l} \pm 91 \\
\pm 68 \\
\pm 3 \\
=4\end{array}$ \\
\hline $\begin{array}{l}1-1-A \\
1-1-B \\
1-3-A \\
1-3-B \\
1-5-A \\
1-5-B \\
1-7-A \\
1-7-B \\
1-9-A \\
1-9-B \\
1-11-A \\
1-11-B \\
1-13-A \\
1-13-B \\
1-15-A \\
1-15-B\end{array}$ & $\begin{array}{l}98 \\
91 \\
93 \\
85 \\
89 \\
99 \\
87 \\
94 \\
95 \\
97 \\
95 \\
88 \\
92 \\
90 \\
84 \\
86\end{array}$ & $\begin{array}{l}869 \\
490 \\
770 \\
840 \\
973 \\
990 \\
955 \\
690 \\
746 \\
808 \\
771 \\
733 \\
846 \\
562 \\
880 \\
765\end{array}$ & $\begin{array}{l}5.268 \\
6.249 \\
8.314 \\
6.904 \\
7.338 \\
7.347 \\
5.362 \\
5.541 \\
5.993 \\
6.735 \\
5.133 \\
6.176 \\
6.854 \\
5.240 \\
5.861 \\
6.228\end{array}$ & $\begin{array}{r}20 \\
<0.6 \\
6.7 \\
<0.6 \\
2.0 \\
2.0 \pm \\
0.84 \pm \\
1.19 \pm \\
10.8 \pm \\
0.90 \pm \\
94 \\
11.2 \pm \\
17.5 \pm \\
<0.6 \pm \\
10.2 \pm \\
<0.6 \pm\end{array}$ & $\begin{array}{l} \pm 2 \\
\pm 0.6 \\
\pm 0.7 \\
\pm 0.6 \\
\pm 0.2 \\
\pm 0.2 \\
\pm 0.1 \\
\pm 0.1 \\
\pm 1.1 \\
\pm 0.1 \\
\pm 9 \\
\pm 1.1 \\
\pm 1.8 \\
\pm 0.6 \\
\pm 1.0 \\
\pm 0.6\end{array}$ \\
\hline $\begin{array}{l}2-2-A \\
2-2-B \\
2-4-A \\
2-4-B \\
2-10-A \\
2-10-B \\
2-12-A \\
2-12-B\end{array}$ & $\begin{array}{l}78 \\
76 \\
80 \\
81 \\
75 \\
74 \\
72 \\
73\end{array}$ & $\begin{array}{r}1006 \\
698 \\
905 \\
820 \\
818 \\
796 \\
950 \\
783\end{array}$ & $\begin{array}{l}7.905 \\
6.646 \\
6.598 \\
4.746 \\
5.788 \\
6.569 \\
8.259 \\
8.009\end{array}$ & $\begin{array}{r}1.83 \pm \\
<0.6 \pm \\
1.44 \pm \\
0.6 \pm \\
5.4= \\
4.1 \pm \\
19.4 \pm \\
1.25 \pm\end{array}$ & $\begin{array}{l} \pm 0.2 \\
\pm 0.6 \\
\pm 0.2 \\
\pm 0.6 \\
\pm 0.5 \\
\pm 0.4 \\
\pm 2.0 \\
\pm 0.2\end{array}$ \\
\hline $\begin{array}{l}3-1-A \\
3-1-B \\
3-5-A \\
3-5-B \\
3-7-A \\
3-7-B \\
3-9-A \\
3-9-B \\
3-13-A \\
3-13-B\end{array}$ & $\begin{array}{l}71 \\
64 \\
69 \\
70 \\
63 \\
62 \\
68 \\
67 \\
65 \\
64\end{array}$ & $\begin{array}{r}1018 \\
522 \\
796 \\
726 \\
1485 \\
806 \\
711 \\
846 \\
527 \\
522\end{array}$ & $\begin{array}{l}7.362 \\
7.408 \\
3.224 \\
7.132 \\
8.033 \\
4.362 \\
8.442 \\
6.692 \\
8.392 \\
7.408\end{array}$ & $\begin{array}{r}0.75 \pm \\
<0.6 \pm \\
1.95 \pm \\
1.82 \pm \\
2.9 \pm \\
3.1 \pm \\
4.3 \pm \\
<0.6 \pm \\
1.01 \pm \\
<0.6 \pm\end{array}$ & $\begin{array}{l} \pm 0.1 \\
\pm 0.6 \\
\pm 0.2 \\
\pm 0.2 \\
\pm 0.3 \\
\pm 0.3 \\
\pm 0.4 \\
\pm 0.6 \\
\pm 0.1 \\
\pm 0.6\end{array}$ \\
\hline $\begin{array}{l}4-2-A \\
4-2-B \\
4-4-A \\
4-4-B \\
4-10-A \\
4-10-B \\
4-12-A \\
4-12-B\end{array}$ & $\begin{array}{l}79 \\
77 \\
56 \\
57 \\
60 \\
61 \\
58 \\
59\end{array}$ & $\begin{array}{l}929 \\
794 \\
878 \\
872 \\
644 \\
697 \\
713 \\
618\end{array}$ & $\begin{array}{l}4.738 \\
4.080 \\
6.496 \\
7.098 \\
6.623 \\
6.641 \\
5.274 \\
5.539\end{array}$ & $\begin{array}{l}<0.6 \pm \\
<0.6 \pm \\
1.23 \pm \\
2.3 \pm \\
0.6 \pm \\
1.2 \pm \\
1.04 \pm \\
1.44 \pm\end{array}$ & $\begin{array}{l} \pm 0.6 \\
\pm 0.6 \\
\pm 0.2 \\
\pm 0.3 \\
\pm 0.1 \\
\pm 0.2 \\
\pm 0.2 \\
\pm 0.2\end{array}$ \\
\hline $\begin{array}{l}\text { 5-3-A Ditch } \\
\text { 5-3-B Ditch } \\
\text { Control A } \\
\text { Control B }\end{array}$ & $\begin{array}{l}82 \\
83 \\
54 \\
55\end{array}$ & $\begin{array}{r}526 \\
868 \\
809 \\
1085\end{array}$ & $\begin{array}{l}6.657 \\
6.273 \\
7.562 \\
5.705\end{array}$ & $\begin{array}{r}<0.6 \pm \\
<0.6 \pm \\
4.8 \pm \\
3.0 \pm\end{array}$ & $\begin{array}{l} \pm 0.6 \\
\pm 0.6 \\
\pm 0.5 \\
\pm 0.3\end{array}$ \\
\hline
\end{tabular}

$\overline{a_{A}=\text { upper } 1.5 \mathrm{dm} ; B}=10$ wer $0.5 \mathrm{dm}$. 
TABLE B-III

IASL URANIUM ANRLYSIS RESULTS: E-F SITE

\begin{tabular}{|c|c|c|c|c|c|}
\hline $\begin{array}{l}\text { LAsL } \\
\text { Sample } \\
\text { No. }\end{array}$ & $\begin{array}{l}\text { Sample } \\
\text { Depth }\end{array}$ & $\begin{array}{r}\text { Lab } \\
\text { No. }\end{array}$ & $\begin{array}{l}\text { Eleld } \\
\text { Weight } \\
\text { (grams) }\end{array}$ & $\begin{array}{l}\text { Lab } \\
\text { Sample } \\
\text { (grams) }\end{array}$ & $\mu q \quad v / g$ \\
\hline $\begin{array}{l}I-1 \\
I-1 \\
I-2 \\
I-2 \\
I-3 \\
I-3 \\
I-4 \\
I-4 \\
I-5 \\
I-5 \\
I-6 \\
I-6 \\
I-7 \\
I-7\end{array}$ & $\begin{array}{l}T-5 \\
L-5 \\
T-5 \\
L-5 \\
T-5 \\
L-5 \\
T-5 \\
L-5 \\
T-5 \\
L-5 \\
T-5 \\
L-5 \\
T-5 \\
L-5\end{array}$ & $\begin{array}{l}175 \\
147 \\
174 \\
176 \\
159 \\
169 \\
142 \\
140 \\
132 \\
136 \\
146 \\
150 \\
152 \\
172\end{array}$ & $\begin{array}{l}780 \\
613 \\
823 \\
552 \\
735 \\
571 \\
661 \\
538 \\
597 \\
580 \\
538 \\
457 \\
530 \\
522\end{array}$ & $\begin{array}{l}7.591 \\
8.740 \\
7.254 \\
6.377 \\
7.651 \\
7.426 \\
6.573 \\
6.573 \\
6.276 \\
6.160 \\
6.845 \\
5.438 \\
5.781 \\
5.730\end{array}$ & $\begin{aligned} 1100 & \neq 110 \\
255 & =26 \\
23400 & =2340 \\
1030 & =103 \\
2500 & =250 \\
800 & =80 \\
780 & =78 \\
213 & \pm 21 \\
1300 & =130 \\
320 & =32 \\
416 & =42 \\
276 & =28 \\
1700 & =170 \\
670 & =67\end{aligned}$ \\
\hline $\begin{array}{l}I-8 \\
I-9 \\
I-9 \\
I-10 \\
I-10 \\
I-11 \\
I-11 \\
I-12 \\
I-12 \\
I-13 \\
I-13 \\
I-14 \\
I-14\end{array}$ & $\begin{array}{l}L-5 \\
T-5 \\
L-5 \\
T-5 \\
L-5 \\
T-5 \\
L-5 \\
T-5 \\
L-5 \\
T-5 \\
L-5 \\
T-5 \\
L-5\end{array}$ & $\begin{array}{l}139 \\
135 \\
163 \\
128 \\
129 \\
134 \\
153 \\
133 \\
131 \\
167 \\
154 \\
170 \\
130\end{array}$ & $\begin{array}{l}951 \\
431 \\
715 \\
543 \\
739 \\
451 \\
755 \\
690 \\
760 \\
618 \\
788 \\
619 \\
706\end{array}$ & $\begin{array}{l}6.238 \\
6.730 \\
6.276 \\
6.140 \\
8.196 \\
5.357 \\
5.169 \\
6.791 \\
7.491 \\
6.325 \\
6.536 \\
5.630 \\
7.296\end{array}$ & $\begin{array}{c}149 \pm 15 \\
265 \pm 27 \\
104 \pm 11 \\
2300 \pm 230 \\
323 \pm 33 \\
1100 \pm 110 \\
2500 \pm 250 \\
1900 \pm 190 \\
1215 \pm 122 \\
1450 \pm 145 \\
1230 \pm 123 \\
2130 \pm 213 \\
2400 \pm 240\end{array}$ \\
\hline $\begin{array}{l}I-15 \\
I I-1 \\
I I-1 \\
I I-2 \\
I I-3 \\
I I-3 \\
I I-4 \\
I I-4 \\
I I-5 \\
I I-5\end{array}$ & $\begin{array}{l}T-5 \\
T-5 \\
L-5 \\
L-5 \\
T-5 \\
L-5 \\
T-5 \\
L-5 \\
T-5 \\
L-5\end{array}$ & $\begin{array}{l}151 \\
155 \\
160 \\
168 \\
157 \\
148 \\
165 \\
161 \\
171 \\
162\end{array}$ & $\begin{array}{l}837 \\
628 \\
645 \\
696 \\
656 \\
734 \\
534 \\
565 \\
538 \\
652\end{array}$ & $\begin{array}{l}5.664 \\
6.206 \\
5.772 \\
7.479 \\
6.247 \\
5.434 \\
6.500 \\
5.713 \\
6.526 \\
7.870\end{array}$ & $\begin{array}{c}2030 \pm 203 \\
1600 \pm 160 \\
171 \pm 17 \\
26 \pm 3 \\
7200 \pm 720 \\
1240 \pm 124 \\
1000 \pm 100 \\
2300 \pm 230 \\
1840 \pm 184 \\
2000 \pm 200\end{array}$ \\
\hline $\begin{array}{l}\text { II-6 } \\
\text { II-6 } \\
\text { II-7 } \\
\text { II-7 } \\
\text { II-8 } \\
\text { II-8 } \\
\text { II-9 } \\
\text { II-9 } \\
\text { II-10 } \\
\text { II-10 }\end{array}$ & $\begin{array}{l}T-5 \\
L-5 \\
T-5 \\
L-5 \\
T-5 \\
L-5 \\
T-5 \\
L-5 \\
T-5 \\
L-5\end{array}$ & $\begin{array}{l}177 \\
173 \\
158 \\
145 \\
144 \\
143 \\
156 \\
137 \\
138 \\
166\end{array}$ & $\begin{array}{r}537 \\
628 \\
572 \\
914 \\
645 \\
1008 \\
613 \\
614 \\
536 \\
740\end{array}$ & $\begin{array}{l}6.737 \\
7.664 \\
5.407 \\
7.234 \\
8.435 \\
8.634 \\
6.386 \\
8.066 \\
7.056 \\
7.919\end{array}$ & $\begin{array}{c}1300 \pm 130 \\
326 \pm 33 \\
1120 \pm 112 \\
263 \pm 26 \\
865 \pm 87 \\
625 \pm 63 \\
3500 \pm 350 \\
1430 \pm 143 \\
600 \pm 60 \\
215 \pm 22\end{array}$ \\
\hline $\begin{array}{l}\text { III-1 } \\
\text { III-1 } \\
\text { III-2 } \\
\text { III I - } \\
\text { IIII-3 } \\
\text { III }-3\end{array}$ & $\begin{array}{l}T-5 \\
L-5 \\
T-5 \\
L-5 \\
T-5 \\
L=5\end{array}$ & $\begin{array}{r}4 \\
33 \\
47 \\
3 \\
44 \\
52\end{array}$ & $\begin{array}{r}646 \\
896 \\
921 \\
1100 \\
853 \\
912\end{array}$ & $\begin{array}{l}4.314 \\
6.363 \\
8.948 \\
5.422 \\
6.310 \\
7.012\end{array}$ & $\begin{array}{c}4520 \pm 450 \\
5500 \pm 550 \\
5100 \pm 510 \\
30000 \pm 3000 \\
2930 \pm 290 \\
1780 \pm 178\end{array}$ \\
\hline
\end{tabular}


TABLE B-III (Continued)

\begin{tabular}{|c|c|c|c|c|c|}
\hline $\begin{array}{l}\text { LASL } \\
\text { Sample } \\
\text { No. }\end{array}$ & $\begin{array}{l}\text { Sample } \\
\text { Deptha }\end{array}$ & $\begin{array}{l}\text { Lat } \\
\text { No. }\end{array}$ & $\begin{array}{l}\text { Field } \\
\text { Weight } \\
\text { (grams) } \\
\end{array}$ & $\begin{array}{l}\text { Lab } \\
\text { Sample } \\
\text { (grams) }\end{array}$ & uq U/a \\
\hline $\begin{array}{l}I I I-4 \\
I I I-4 \\
I I I-6 \\
I I I-6 \\
I I I I-7 \\
I I I-7 \\
I I I-8 \\
I I I-8 \\
I I I-9 \\
I I I-9\end{array}$ & $\begin{array}{l}T-5 \\
L-5 \\
T-5 \\
L-5 \\
T-5 \\
L-5 \\
T-5 \\
L-5 \\
T-5 \\
L-5\end{array}$ & $\begin{array}{l}8 \\
49 \\
12 \\
14 \\
11 \\
50 \\
13 \\
9 \\
43 \\
46\end{array}$ & $\begin{array}{l}802 \\
913 \\
596 \\
716 \\
546 \\
689 \\
526 \\
833 \\
514 \\
862\end{array}$ & $\begin{array}{l}3.381 \\
9.035 \\
4.800 \\
5.350 \\
4.947 \\
5.207 \\
1.955 \\
3.412 \\
6.348 \\
5.811\end{array}$ & $\begin{array}{c}1660: 166 \\
2200: 220 \\
646 \geq 65 \\
252 \pm 25 \\
950 \pm 95 \\
220 \pm 22 \\
525 \pm 53 \\
75 \pm 8 \\
386 \pm 39 \\
78: 8\end{array}$ \\
\hline $\begin{array}{l}I I I-10 \\
I I I-10 \\
I I I-11 \\
I I I-1 I\end{array}$ & $\begin{array}{l}T-5 \\
L-5 \\
T-5 \\
L-5\end{array}$ & $\begin{array}{l}38 \\
37 \\
34 \\
39\end{array}$ & $\begin{array}{l}628 \\
628 \\
678 \\
761\end{array}$ & $\begin{array}{l}4.513 \\
4.211 \\
4.369 \\
6.657\end{array}$ & $\begin{array}{c}886 \div 89 \\
250 \pm 25 \\
7550=755 \\
158 \div 16\end{array}$ \\
\hline 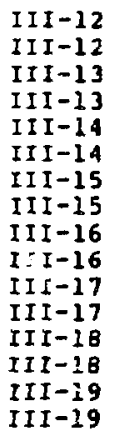 & $\begin{array}{l}T-5 \\
L-5 \\
T-5 \\
L-5 \\
T-5 \\
L-5 \\
T-5 \\
L-5 \\
T-5 \\
L-5 \\
T-5 \\
L-5 \\
T-5 \\
L-5 \\
T-5 \\
L-5\end{array}$ & $\begin{array}{r}1 \\
35 \\
36 \\
5 \\
26 \\
18 \\
30 \\
29 \\
53 \\
6 \\
10 \\
24 \\
10 \\
27 \\
32 \\
18\end{array}$ & $\begin{array}{l}746 \\
819 \\
607 \\
672 \\
516 \\
646 \\
552 \\
739 \\
579 \\
982 \\
642 \\
780 \\
653 \\
626 \\
779 \\
893\end{array}$ & $\begin{array}{l}4.350 \\
6.146 \\
5.185 \\
4.182 \\
5.151 \\
8.528 \\
6.597 \\
5.430 \\
6.789 \\
5.440 \\
5.072 \\
4.153 \\
5.326 \\
6.659 \\
5.586 \\
5.003\end{array}$ & $\begin{aligned} 1240 & : 124 \\
264 & =27 \\
1810 & : 181 \\
660 & : 66 \\
1710 & : 171 \\
1470 & : 147 \\
675 & : 68 \\
285 & : 29 \\
1840 & \pm 184 \\
98: 3 & \pm 98 \\
1450 & \pm 146 \\
1590 & \pm 159 \\
1760 & =176 \\
116 & \pm 12 \\
1350 & \pm 135 \\
320 & \pm 32\end{aligned}$ \\
\hline
\end{tabular}

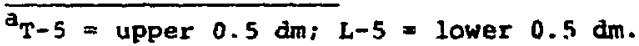


TABLE B-IV

LASL: URANIUM ANALYSIS RESULTS

Lower Slobovia

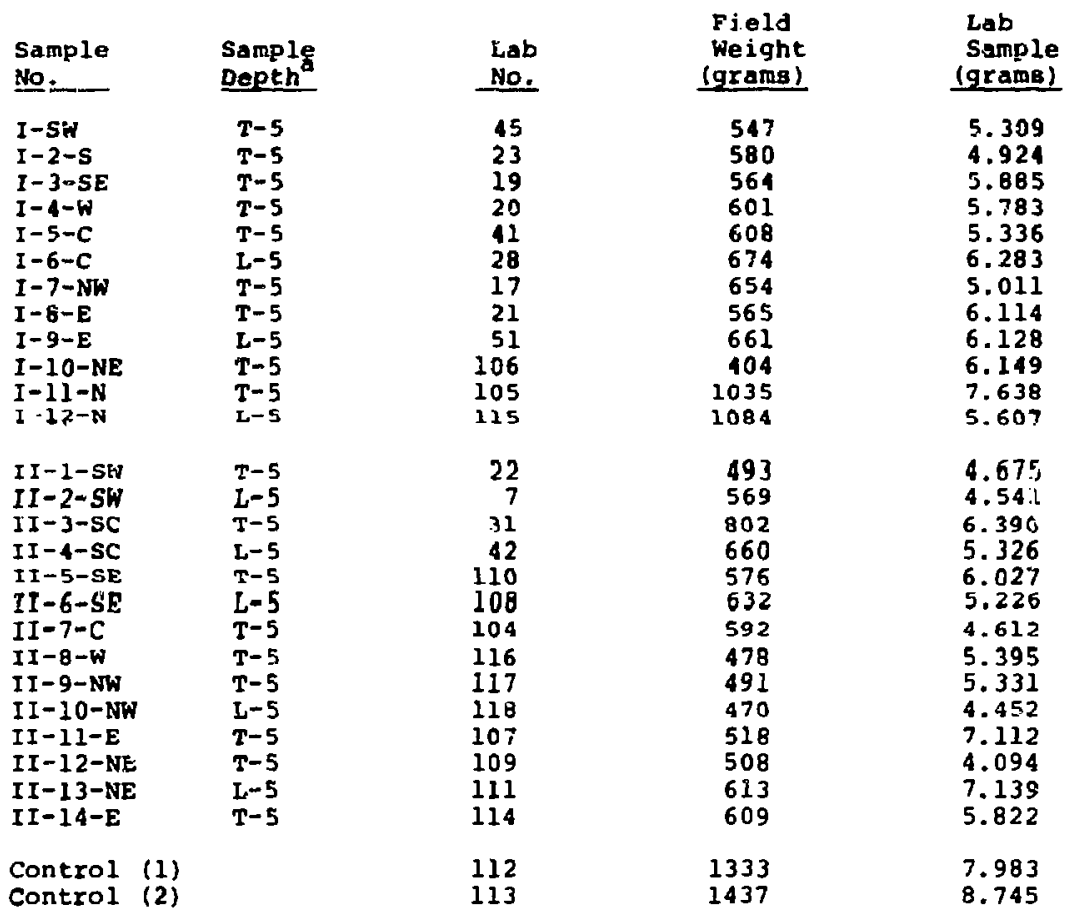

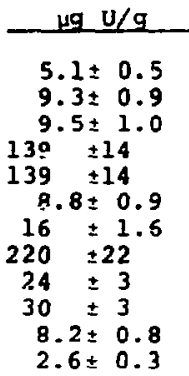

$19 \pm 2$

$14 \pm 1.4$

$2.7 \pm 0.3$

$0.6 \pm 0.6$

$1.54=0.2$

$0.9 \pm 0.1$

$27 \pm 3$

$46 \pm 5$

$7.5 \pm 0.8$

$2.7 \pm 0.3$

$23 \pm 2$

$4.8 \pm 0.5$

$0.6 \pm 0.6$

$25 \pm 3$

$1.88 \pm 0.2$

$0.6 \pm 0.6$

Minie Site

127
126
120
123
121
124
122
125
119

5.639

6.610

8.172

4.977

8.561

6.435

5.369

6.818

7.021

$$
\begin{aligned}
5.9 & \pm 0.6 \\
5.3 & \pm 0.5 \\
0.71 & \pm 0.07 \\
12.3 \pm 1.2 & \pm 1.2 \\
0.99 & \pm 0.10 \\
1.79 & \pm 0.18 \\
0.6 & \pm 0.6 \\
2.3 & \pm 0.2 \\
2.8 & \pm 0.3
\end{aligned}
$$

$\overline{a_{T-5}=\text { upper } 0.5 \mathrm{dm}} ; \mathrm{L}-5=$ lower $0.5 \mathrm{dm}$. 
APPENDIX C

QUALITY CONTROL DATA FOR LASL URANIUM ANALYSES

\begin{tabular}{|c|c|c|c|c|c|c|c|c|c|c|c|}
\hline \multirow{2}{*}{$\frac{\text { Sample }}{-0-0-A-(A)}$} & & \multirow{2}{*}{$\begin{array}{c}\begin{array}{c}\text { Waight } \\
\text { (grams) }\end{array} \\
4.676 \\
4.604 \\
4.415\end{array}$} & \multirow{2}{*}{$\begin{array}{l}\text { Sample } \\
\begin{array}{l}1.11 \\
1.22 \\
7.9\end{array}\end{array}$} & \multicolumn{3}{|c|}{$\begin{array}{l}\text { Fluonametric Readings } \\
\text { (mg } U / g \text { ) }\end{array}$} & \multicolumn{2}{|c|}{$\begin{array}{l}\text { Spiked Sample }{ }^{a} \\
\text { (mg } \mathrm{U} / \mathrm{g})\end{array}$} & \multirow{2}{*}{$\begin{array}{l}\mathrm{mg} \mathrm{v} / \mathrm{g} \\
1.05 \\
1.04 \\
8.0\end{array}$} & \multirow{2}{*}{$\begin{array}{l}\text { Sample } \\
\begin{array}{l} \pm 0.03 \\
\pm 0.12 \\
\pm 0.2\end{array}\end{array}$} & \multirow{2}{*}{$\begin{array}{c}\text { CV } \\
0.03 \\
0.12 \\
0.03\end{array}$} \\
\hline & & & & $\begin{array}{l}1.06 \\
1.10 \\
8.3\end{array}$ & $\begin{array}{l}1.02 \\
0.87 \\
7.9\end{array}$ & $\begin{array}{l}1.02 \\
0.97 \\
8.3\end{array}$ & $\begin{array}{l}1.03 \\
1.00 \\
7.8\end{array}$ & $\begin{array}{l}1.05 \\
1.09 \\
7.8\end{array}$ & & & \\
\hline $\begin{array}{l}1-1-A-(A) \\
1-1-A-(B) \\
1-1-A-(C)\end{array}$ & & $\begin{array}{l}4.994 \\
4.616 \\
4.717\end{array}$ & $\begin{array}{l}0.027 \\
0.015 \\
0.012\end{array}$ & $\begin{array}{l}0.027 \\
0.011 \\
0.012\end{array}$ & $\begin{array}{l}0.029 \\
0.009 \\
0.012\end{array}$ & $\begin{array}{l}0.029 \\
0.019 \\
0.010\end{array}$ & $\begin{array}{l}0.039 \\
0.011 \\
0.033\end{array}$ & $\begin{array}{l}0.042 \\
0.015 \\
0.039\end{array}$ & $\begin{array}{l}0.032^{c} \\
0.013^{c} \\
0.020^{c}\end{array}$ & & $\begin{array}{l}0.22 \\
0.31 \\
0.65\end{array}$ \\
\hline $\begin{array}{ll}5 & \mathrm{LS}-1 \mathrm{C}-\mathrm{T}-5 \\
5 & \mathrm{LS}-1 \mathrm{C}-\mathrm{T}-5 \\
5 & \mathrm{LS}-1 \mathrm{C}-\mathrm{T}-5\end{array}$ & $\begin{array}{l}\text { (A) } \\
\text { (B) } \\
\text { (C) }\end{array}$ & $\begin{array}{l}4.262 \\
4.388 \\
4.155\end{array}$ & $\begin{array}{l}0.019 \\
0.016 \\
0.014\end{array}$ & $\begin{array}{l}0.018 \\
0.011 \\
0.013\end{array}$ & $\begin{array}{l}0.023 \\
0.013 \\
0.014\end{array}$ & $\begin{array}{l}0 . \\
0 .\end{array}$ & & & & & $\begin{array}{l}0.04 \\
0.33 \\
0.71\end{array}$ \\
\hline $\begin{array}{ll}2 & \mathrm{EF}-\mathrm{FP}-\mathrm{T}-5 \\
2 & \mathrm{EF}-\mathrm{FP}-\mathrm{T}-5 \\
2 & \mathrm{EF}-\mathrm{FP}-\mathrm{T}-5\end{array}$ & $\begin{array}{l}\text { (A) } \\
(B) \\
(C)\end{array}$ & $\begin{array}{l}4.371 \\
4.332 \\
4.369\end{array}$ & $\begin{array}{l}4.3 \\
2.5 \\
4.5\end{array}$ & $\begin{array}{l}4.3 \\
3.3 \\
5.6\end{array}$ & $\begin{array}{l}4.6 \\
2.9 \\
4.7\end{array}$ & & & $\begin{array}{l}4.6 \\
3.8 \\
4.6\end{array}$ & $\begin{array}{l}4 \\
3\end{array}$ & & $\begin{array}{l}0.16 \\
0.04\end{array}$ \\
\hline $\begin{array}{ll}3 & E F-F P-T-5 \\
3 & E F-F P-T-5 \\
3 & E F-F P-T-5\end{array}$ & $\begin{array}{l}\text { (A) } \\
\text { (B) } \\
\text { (C) }\end{array}$ & $\begin{array}{l}4.402 \\
4.516 \\
4.157\end{array}$ & $\begin{array}{l}2.7 \\
2.8 \\
2.6\end{array}$ & $\begin{array}{l}2.7 \\
2.8 \\
2.5\end{array}$ & $\begin{array}{l}2.4 \\
2.2 \\
2.3\end{array}$ & $\begin{array}{l}2.2 \\
2.3\end{array}$ & $\begin{array}{l}2.4 \\
2.5 \\
2.5\end{array}$ & $\begin{array}{l}2.5 \\
2.3 \\
2.5\end{array}$ & $\begin{array}{l}2.5 \\
2.5 \\
2.4\end{array}$ & & $\begin{array}{l}0.11 \\
0.05\end{array}$ \\
\hline $\begin{array}{ll}12 & \mathrm{EF}-\mathrm{FP}-\mathrm{T}-5 \\
12 & \mathrm{EF}-\mathrm{FP}-\mathrm{T}-5 \\
12 & \mathrm{EF}-\mathrm{FP}-\mathrm{T}-5\end{array}$ & $\begin{array}{l}\text { (A) } \\
\text { (B) }\end{array}$ & $\begin{array}{l}4.642 \\
4.255 \\
4.117\end{array}$ & $\begin{array}{l}1.23 \\
1.18 \\
1.18\end{array}$ & $\begin{array}{l}1.16 \\
1.23 \\
1.14\end{array}$ & $\begin{array}{l}0.81 \\
1.12 \\
1.15\end{array}$ & $\begin{array}{l}1.11 \\
1.18 \\
1.09\end{array}$ & $\begin{array}{l}1.21 \\
1.19 \\
1.17\end{array}$ & $\begin{array}{l}1.06 \\
1.22 \\
1.15\end{array}$ & $\begin{array}{l}1.10 \\
1.19 \\
1.15\end{array}$ & $\begin{array}{l} \pm 0.15 \\
\pm 0.04 \\
\pm 0.03\end{array}$ & $\begin{array}{l}0.14 \\
0.03 \\
0.03\end{array}$ \\
\hline $\begin{array}{ll}6 & \mathrm{EF}-\mathrm{FP}-\mathrm{T}-5 \\
6 & \mathrm{EF}-\mathrm{FP}-\mathrm{T}-5 \\
6 & \mathrm{EF}-\mathrm{FP}-\mathrm{T}-5\end{array}$ & $\begin{array}{l}\text { (A) } \\
\text { (B) }\end{array}$ & $\begin{array}{l}4.332 \\
4.575 \\
4.238\end{array}$ & $\begin{array}{l}0.39 \\
0.56 \\
0.58\end{array}$ & $\begin{array}{l}0.58 \\
0.52 \\
0.59\end{array}$ & $\begin{array}{l}0.58 \\
0.67 \\
0.73\end{array}$ & $\begin{array}{l}0.42 \\
0.75 \\
0.67\end{array}$ & $\begin{array}{l}0.57 \\
0.62 \\
0.67\end{array}$ & $\begin{array}{l}0.57 \\
0.69 \\
0.54\end{array}$ & $\begin{array}{l}0.52 \\
0.64 \\
0.63\end{array}$ & $\begin{array}{l} \pm 0.09 \\
\pm 0.09 \\
\pm 0.07\end{array}$ & $\begin{array}{l}0.17 \\
0.14 \\
0.11\end{array}$ \\
\hline
\end{tabular}

$\overline{a_{2} \mu g / g ~} \mathrm{U}$ added before analysis and later substracted from the results to check iron interferences with fluorometric data.

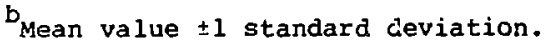

cNear detectable limit. 